Review

\title{
A Review of Polyphenolics in Oak Woods
}

\section{Bo Zhang ${ }^{1,2}$, Jian Cai ${ }^{1,3}$, Chang-Qing Duan ${ }^{1}$, Malcolm J. Reeves ${ }^{1,4}$ and Fei He ${ }^{1, *}$}

1 Center for Viticulture and Enology, College of Food Science and Nutritional Engineering, China Agricultural University, Beijing 100083, China; E-Mails: zb692002@163.com (B.Z.); caijian928@cau.edu.cn (J.C.); chqduan@cau.edu.cn (C.-Q.D.); mreeves@xtra.co.nz (M.J.R.)

2 College of Food Science and Engineering, Gansu Agricultural University, Lanzhou 730070, China

3 College of Agronomy and Biotechnology, China Agricultural University, Beijing 100094, China

4 Institute of Food, Nutrition and Human Health, Massey University, Palmerston North 4442, New Zealand

* Author to whom correspondence should be addressed; E-Mail: wheyfey@cau.edu.cn; Tel.: +86-10-6273-7039; Fax: +86-10-6273-8658.

Academic Editor: Vladimír Křen

Received: 18 December 2014 / Accepted: 13 February 2015 / Published: 27 March 2015

\begin{abstract}
Polyphenolics, which are ubiquitous in plants, currently are among the most studied phytochemicals because of their perceptible chemical properties and antioxidant activity. Oak barrels and their alternatives, which are widely used in winemaking nowadays, contribute polyphenolics to wines and are thought to play crucial roles in the development of wines during aging. This study summarizes the detailed information of polyphenolics in oak woods and their products by examining their structures and discussing their chemical reactions during wine aging. This paper evaluates the most recent developments in polyphenolic chemistry by summarizing their extraction, separation, and their identification by the use of chromatographic and spectral techniques. In addition, this paper also introduces polyphenol bioactive ingredients in other plant foods.
\end{abstract}

Keywords: oak; polyphenolics; structure; wine aging; analysis

\section{Introduction}

It was possibly the Celts who invented wooden barrels that were nearly identical to the basic forms used today. In the third century B.C., these barrels gradually replaced amphoras as the main containers 
for wine transportation [1]. Ancient Mesopotamians initially used barrels made of palm wood, although not for wine. However, it is difficult to bend and fashion palm wood into barrels and so their use was limited, especially for liquids. With the various limitations of palm wood, wine merchants in different regions experimented with various wood sources to find the better materials for barrel making [2]. The use of oak for barrel production had been prevalent for about 2000 years, and the earliest literature on use of oak can be traced back to the Roman Empire. With the passage of time, winemakers discovered that wine aging in oak barrels was not only convenient, but also improved wine quality by improving their appearances, flavors and mouth feel, therefore, aging wines in oak barrels became an indispensable part of making high-quality wines [2-4]. Given the unique mechanical, physical, and chemical properties of oak wood, especially oak heartwood, it emerged as being particularly suitable not only for shipping wine but also for its development with time.

Oak is an angiosperm belonging to the Fagacea family. Approximately 600 species of the genus Quercus are distributed worldwide, and the basic composition of oak does not significantly differ from one species to another. Cellulose (40\%) and hemicellulose $(25 \%)$, which provide the framework and matrix of the woods, are the main compounds of oak woods, and lignin, another large polymer mainly present in the cell walls, also comprises $20 \%$ of dried oak wood $[5,6]$.

American white oak $(Q$. alba) and French red oak (Q. robur and $Q$. petraea) are three of the most frequently used sources of oak woods in coopering [7]. Some previous studies also focused on examining new types and new regions of oak wood from Spain, Russia and other Eastern Europe countries (Ukraine, Romania, Hungary), even in China, with a view to sustaining the existing oak resources by finding suitable new alternatives and suppliers [8-10]. Relevant studies showed that wines aged in Spanish oak barrels had characteristics similar to those of the same wines aged in French oak barrels. However, the wines aged in American oak barrels usually showed significant differences compared with the wines aged in Spanish counterparts. Some results suggested that Eastern Europe oak contained higher levels of aromatic substances, such as volatile phenols and phenolic aldehydes, than French oak, even though they were of the same species [10,11]. These findings demonstrated the prospects of new oak sources for the wine industry, and such sources might soon compete with traditional ones.

Generally speaking, oak barrel aging of wines is considered as a traditional and standard part of winemaking to yield high-quality wines. During aging, various soluble oak components diffuse into the wine and enhance the intensity and complexity of wine flavors [11]. Volatile phenols and benzoic aldehydes play a very important role in contributing to the sensorial characteristics of the wines $[12,13]$. Hydrolyzable tannins such as ellagitannins, are particularly significant because they confer astringency, as well as being involved in the stabilization of pigment structures [14]. Moreover, during aging, micro-amounts of oxygen penetrate into the wine due to the slightly porous nature of the oak grain. This slow infusion improves the quality of red wines, especially in terms of color, aroma, and taste [15-19]. Thus, during aging in oak barrels, wines acquire better color, more delicate aromas and greater roundness, improve their harmony in taste profile, and decrease the intensities of green and woody characters. Furthermore, the aging process is not only a critical step in improving the sensory properties of wines but also in acquiring health protective properties. These properties include an increase in antioxidant activity, anticarcinogenic properties, and free radical scavenging capacity [20-22].

Such benefits have stimulated the considerable researches into the roles of oak in wine aging over several decades. Many studies focused on the composition and function of oak, and how it contributed 
to improve wine quality. Therefore, the present review covers the following: (1) The basic structures of plant polyphenolic components; (2) The polyphenolic compositions of different types of oak; (3) The factors that influence oak polyphenolic compositions; (4) The available methods for the extraction, separation, and characterization of the polyphenolic compounds in oak woods and other plant sources with similar polyphenolic compositions; and finally (5) The polyphenol bioactive ingredients in other plant foods.

\section{Classification of Plant Polyphenols}

Polyphenolics constitute one of the most numerous and widely distributed groups of substances in the plant kingdom, currently with over 8000 known phenolic structures published [23]. These compounds can be subdivided into different classes according to the number of their phenol rings and the structural elements linked to the basic units [24]. Table 1 shows a general classification of the 21 principal structures based on the number of carbons in the molecule.

Table 1. Classification of phenolic compounds in plants [24].

\begin{tabular}{cc}
\hline Structure & Phenolic Class \\
\hline $\mathrm{C}_{6}$ & Simple phenolics \\
$\mathrm{C}_{6}-\mathrm{C}_{1}$ & Phenolic acids and related compounds \\
$\mathrm{C}_{6}-\mathrm{C}_{2}$ & Acetophenones and phenylacetic acids \\
$\mathrm{C}_{6}-\mathrm{C}_{3}$ & Cinnamic acids, cinnamyl aldehydes/alcohols \\
$\mathrm{C}_{6}-\mathrm{C}_{3}$ & Coumarins, isocoumarins, chromones \\
$\mathrm{C}_{6}-\mathrm{C}_{1}-\mathrm{C}_{6}$ & Benzophenones, xanthones \\
$\mathrm{C}_{6}-\mathrm{C}_{2}-\mathrm{C}_{6}$ & Stilbenes \\
$\mathrm{C}_{6}-\mathrm{C}_{3}-\mathrm{C}_{6}$ & Chalcones, aurones, dihydrochalcones \\
$\mathrm{C}_{6}-\mathrm{C}_{3}-\mathrm{C}_{6}$ & Flavones \\
$\mathrm{C}_{6}-\mathrm{C}_{3}-\mathrm{C}_{6}$ & Flavonols \\
$\mathrm{C}_{6}-\mathrm{C}_{3}-\mathrm{C}_{6}$ & Flavanones \\
$\mathrm{C}_{6}-\mathrm{C}_{3}-\mathrm{C}_{6}$ & Flavanonols \\
$\mathrm{C}_{6}-\mathrm{C}_{3}-\mathrm{C}_{6}$ & Flavan-3-ols \\
$\mathrm{C}_{6}-\mathrm{C}_{3}-\mathrm{C}_{6}$ & Isoflavonoids \\
$\mathrm{C}_{6}-\mathrm{C}_{3}-\mathrm{C}_{6}$ & Anthocyanidins/Anthocyanins \\
$\left(\mathrm{C}_{6}-\mathrm{C}_{3}-\mathrm{C}_{6}\right)_{2}$ & Biflavonoids \\
$\mathrm{C}_{6}, \mathrm{C}_{10}, \mathrm{C}_{14}$ & Betacyanins \\
$\mathrm{C}_{18}$ & Dimers or oligomers \\
Lignans, neolignans & Polymers \\
Lignin & Polymers \\
Phlobaphenes & \\
\hline
\end{tabular}

These secondary molecules accumulate in plants and participated in defense mechanisms against the ultraviolet radiation or the aggression by pathogens. Generally, polyphenol skeletons are derived from two different active precursors (i.e., 4-coumaroyl-CoA and malonyl-CoA), and they arise biogenetically from acetate and shikimate pathways (Figure 1). 


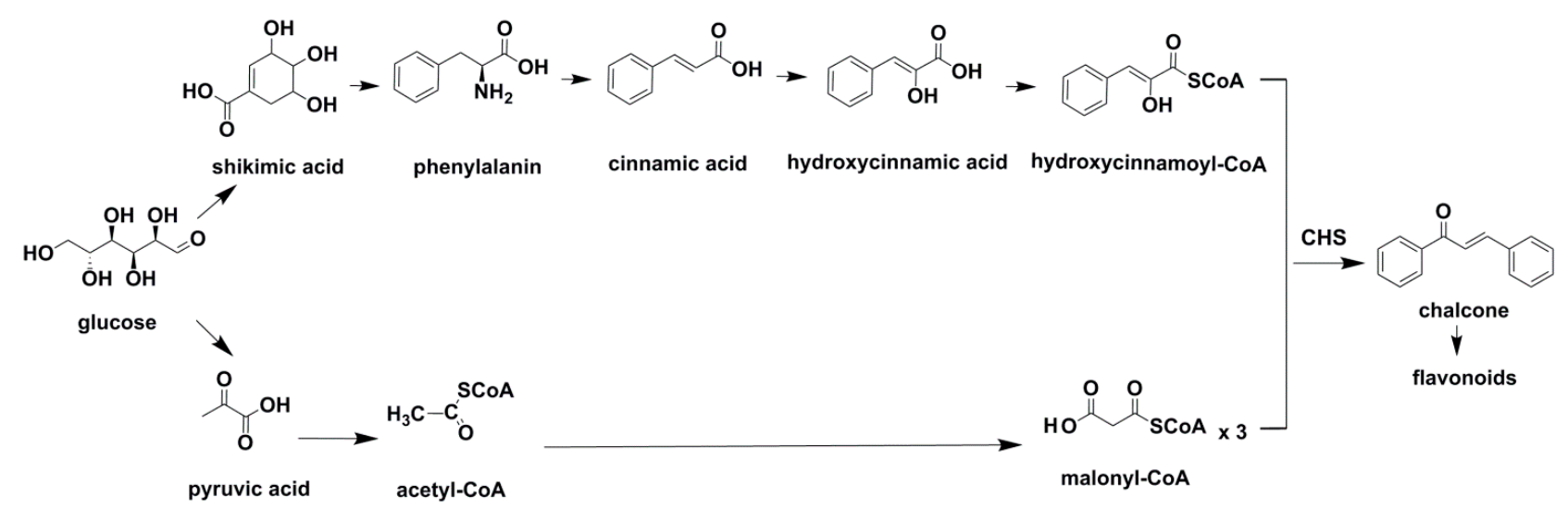

Figure 1. Scheme of the biosynthetic pathways of polyphenolic compounds [25].

Relevant studies showed that both synthetic pathways were derived from glucose metabolism. In addition, the two main precursors could be joined by a condensation reaction catalyzed by chalcone synthase (CHS) to be converted into flavonoids, which are the most abundant and important group of polyphenol compounds $[26,27]$. Therefore, another classification system could be established according to the flavonoid or non-flavonoid structures of the aforementioned compounds.

Flavonoid chemical skeletons are based on $\mathrm{C} 15\left(\mathrm{C}_{6}-\mathrm{C}_{3}-\mathrm{C}_{6}\right)$ compounds, all of which share a common diphenyl propane structure with two aromatic rings (ring A and B) joined through a group of three carbon atoms to yield an oxygenated heterocycle (ring C). Flavonoids also occasionally occur in plants as $O$ - or $C$-glycosides. The preferred glycosylation sites of these compounds are the $\mathrm{C}_{3}$ position of the $\mathrm{C}$ ring, or $\mathrm{C}_{5}$ position of the A ring, and less frequently, the $\mathrm{C}_{7}$ site of flavonoid structures. Glucose is the most common sugar residue of flavonoids, but others include rhamnose, xylose, and galactose [28-30]. Based on experimental determination, the arrangement of $\mathrm{C} 3$ group determines their classification. Normally, flavonoids consist mainly of monomeric flavanols (catechins and leucoanthocyanidins), polymeric flavanols (proanthocyanidins), and chalcones, flavonols, flavanones, and anthocyanidins, which were all biosynthesized in the flavonoid pathway. Besides, isoflavonoids, biflavonoids, and neoflavanoids were also studied [31,32]. Table 2 gives the basic chemical structures of the main flavonoid compounds.

Table 2. The basic chemical structure of the main flavonoids compounds [31].

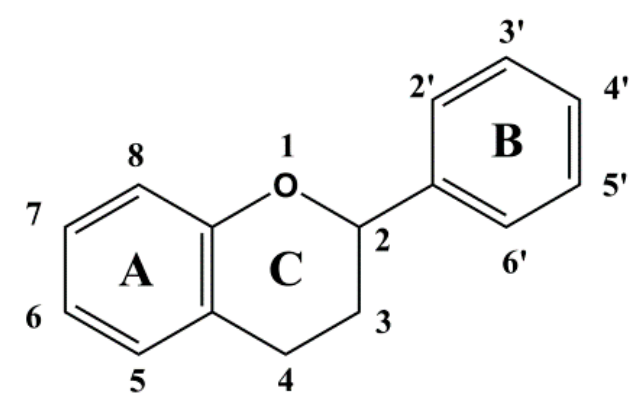


Table 2. Cont.

Flavonoids
Chalcones
Aurones
Flavonols
Dihydroflavonols
Flavanones
Flavanols
Isoflavonoids
Biflavonoids
Anthocyanidins

The non-flavonoid phenolic constituents in plants can be mainly classified into hydroxybenzoic acids, hydroxycinnamic acids, volatile phenols, stilbenes, and miscellaneous compounds (e.g., lignans and coumarins) $[33,34]$. Hydroxybenzoic acids are organic compounds that contain a phenolic ring and an associated carboxylic group, making a $\mathrm{C}_{6}-\mathrm{C}_{1}$ structure. The most common derivatives of hydroxybenzoic acid found in plants are gallic, vanillic, $p$-hydroxybenzoic, syringic, and protocatechuic acids [33]. Hydroxycinnamic acids, which were widely distributed in plant-originated food products, are a class of polyphenols with a $\mathrm{C}_{6}-\mathrm{C}_{3}$ skeleton, and exist either in free form or associated with other components, such as quinic acid or polysaccharides [35,36]. Furthermore, volatile phenols possess aroma characteristics, and stilbenes can act as phytoalexins, which also contribute to flavor and potent biological activities for plants, respectively.

Unlike the classes of plant polyphenolics described above, tannin is a term applied to a large group of polyphenolics, which have a wide range of structures and are of intermediate to high molecular weight. Plant tannins are conventionally classified into two major classes: condensed and hydrolyzable tannins [28]. Condensed tannins, also known as proanthocyanidins, are widespread in all ferns, gymnosperms, and some angiosperms, which have flavonoid cores as their main basic unit (see the structure in Table 2) [37]. Hydrolyzable tannins, such as gallotannins and ellagitannins are polymers of glucose esters of gallic acids and hexahydroxydiphenic acids respectively, with molecular masses ranging from 500 to $5000 \mathrm{Da}$, which are only encountered in 15 of the 40 orders of dicotyledons [38]. Figure 2 illustrates the basic structures of hydrolyzable tannins. 


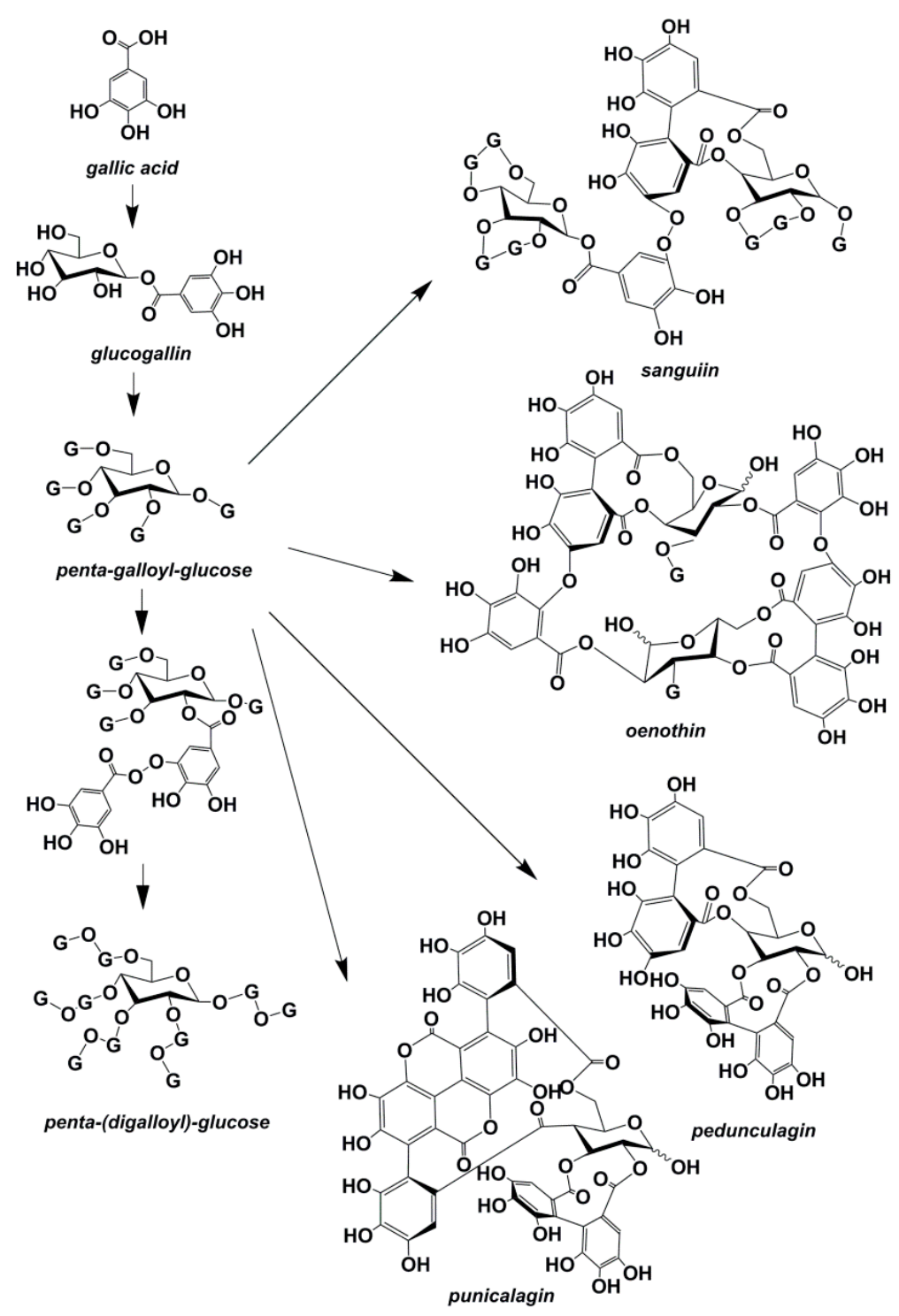

Figure 2. Structures of hydrolyzable tannins [39].

\section{Oak Polyphenolics}

Polyphenolic compounds found in oak wood have important functions in aged wines. Not only do oak polyphenols have an essential role in wine maturation but also feature as influencing factors associated with potent antioxidant effects [40]. These compounds are normally classified into three main classes: volatile phenols, phenolic acids and ellagitannins. In structure, both volatile phenols and phenolic acids are derived from the simple phenol structure of hydroxybenzene, which is an aromatic ring, whereas ellagitannins are a diverse class of hydrolyzable tannins, a type of polyphenol formed primarily from the oxidative linkage of galloyl groups in $\beta-1,2,3,4,6$-pentagalloyl glucose.

\subsection{Volatile Phenols}

Volatile phenols are simple phenols in oak woods that can be extracted into wines, modifying their aroma compound profiles. Traces 4 -vinylphenol was found in oak, but its content could approach the olfactory thresholds $(605 \mu \mathrm{g} / \mathrm{L})$ in wines aged over a long period of time, causing aromas described as 
"stable" and "medicinal" [41]. 4-Ethylphenol, another phenol derivative found in oak-aged wines, had horsey, leather, and sweaty saddle-like descriptors when its concentration was above $425 \mu \mathrm{g} / \mathrm{L}$ [42]. In contrast, guaiacol and its derivatives possess lower olfactory thresholds. Guaiacol and 4-methylguaiacol, which have smoky and spicy aromas have olfactory thresholds of 25 and $65 \mu \mathrm{g} / \mathrm{L}$, respectively [43]. 4-Ethylguaicol with a $33 \mu \mathrm{g} / \mathrm{L}$ olfactory threshold also contributes spicy, toasted, and smoky aromas. Vinylguaiacol, with an olfactory detection threshold of $40 \mu \mathrm{g} / \mathrm{L}$, contributes spicy, clove-like, and oak aromas $[43,44]$.

Some studies showed that ethylphenol, vinylphenol and vinylguaiacol were present at low concentrations in oak wood. However, the amounts found in wines are mainly from the action of microorganisms. Microorganisms in the barrel, especially lactic bacteria and yeasts, are associated with these off flavors [45], such as ethylphenol, which its occurrence is normally attributed to the action of Brettanomyces yeast rather than oak directly. On the other hand, 4-vinylphenol and 4-vinylguaiacol could adduct with anthocyanins at their $\mathrm{C}_{4}$ and $\mathrm{C}_{5}$ positions and then undergo an oxidation process, incorporated into the pyran ring in the resulting pyranoanthocyanins. Such addition compounds could change the anthocyanin color to orange and protect the anthocyanins from hydration and so stabilize the anthocyanin pigments [46]. Figure 3 presents the formation of such an anthocyanidin-3-O-glucoside-vinylphenol adduct.

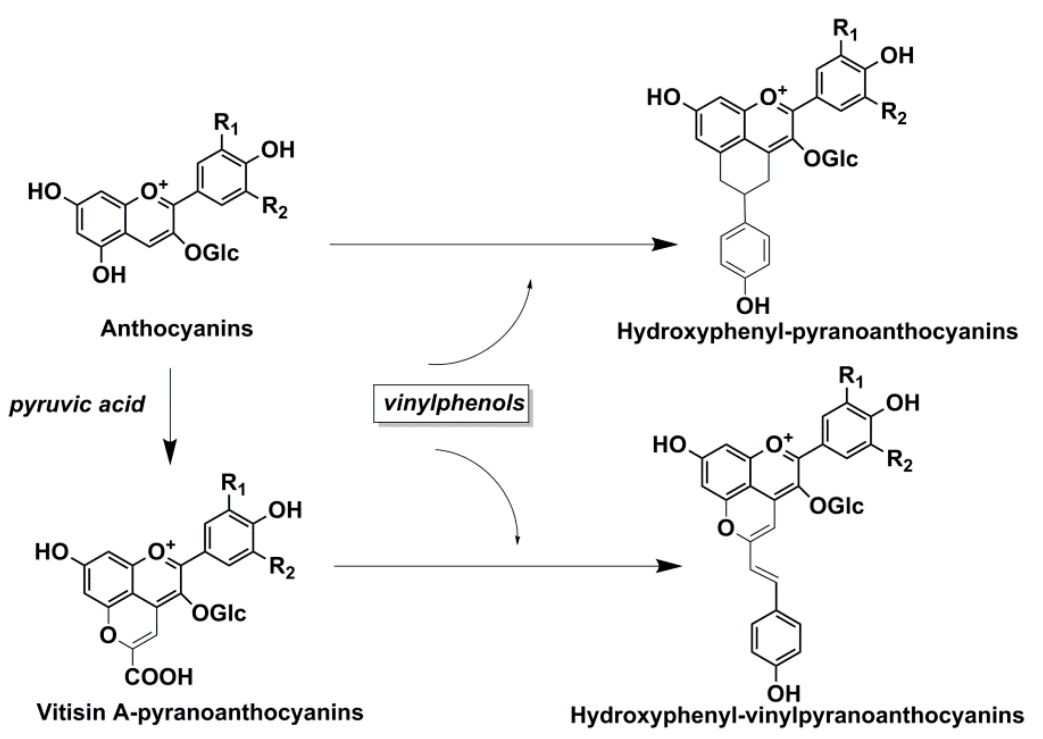

Figure 3. Formation of the anthocyanin-vinylphenol adducts [46].

\subsection{Phenolic Acid}

The main phenolic acids compounds identified in some seasoned and toasted oak are hydroxybenzoic and hydroxycinnamic acids [10]. Hydroxybenzoic acids which are derived directly from benzoic acid, include gallic, gentisic, $p$-hydroxybenzoic, protocatechuic, syringic, salicylic, and vanillic acids (Figure 4a). Related compounds also include hydroxybenzoic aldehydes, such as syringaldehyde and vanillin, which are modified as aldehydes with carboxyl groups. Hydroxycinnamic acids and their derivatives had the $\mathrm{C}_{6}-\mathrm{C}_{3}$ structures. The most common hydroxycinnamic acids in oak woods are $p$-coumaric, caffeic, ferulic acids, and sinapic acid (Figure 4b). Table 3 lists phenolic acids that have been reported in literatures. 
a<smiles>[R]c1cc(C(=O)O)c([R])c([R9])c1[2H]</smiles>

$\mathbf{R}_{1}=\mathbf{R}_{2}=\mathbf{R}_{3}=\mathrm{OH}, \mathbf{R}_{\mathbf{4}}=\mathrm{H}$ : gallic acid

$\mathbf{R}_{1}=\mathbf{R}_{\mathbf{4}}=\mathrm{OH}, \mathbf{R}_{\mathbf{2}}=\mathbf{R}_{\mathbf{3}}=\mathrm{H}$ : Gentisic acid

$\mathbf{R}_{1}=\mathbf{R}_{\mathbf{3}}=\mathbf{R}_{\mathbf{4}}=\mathrm{H}, \mathbf{R}_{\mathbf{2}}=\mathrm{OH}$ : $\boldsymbol{p}$-hydroxybenzoic acid

$\mathbf{R}_{\mathbf{1}}=\mathbf{R}_{\mathbf{4}}=\mathrm{H}, \mathbf{R}_{\mathbf{2}}=\mathbf{R}_{\mathbf{3}}=\mathrm{OH}$ : protocathechuic acid

$\mathbf{R}_{1}=\mathbf{R}_{3}=\mathrm{OCH}_{3}, \mathbf{R}_{2}=\mathrm{OH}, \mathbf{R}_{4}=\mathrm{H}$ : Syringic acid

$\mathbf{R}_{1}=\mathbf{R}_{\mathbf{2}}=\mathbf{R}_{\mathbf{3}}=\mathrm{H}, \mathbf{R}_{\mathbf{4}}=\mathrm{OH}$ : salicylic acid

$\mathbf{R}_{1}=\mathbf{R}_{4}=\mathrm{H}, \mathbf{R}_{2}=\mathrm{OH}, \mathbf{R}_{3}=\mathrm{OCH}_{3}$ : vanillic acid b<smiles>[R]c1cc(/C=C(\O)C(=O)O)cc([R9])c1O</smiles>

$\mathbf{R}_{\mathbf{1}}=\mathbf{R}_{\mathbf{2}}=\mathrm{H}:$ $\boldsymbol{p}$-Coumaric acid

$\mathbf{R}_{1}=\mathbf{H}, \mathbf{R}_{\mathbf{2}}=\mathrm{OH}$ : Caffeic acid

$\mathbf{R}_{1}=\mathbf{H}, \mathbf{R}_{2}=\mathrm{OCH}_{3}$ : Ferulic acid

$\mathbf{R}_{1}=\mathbf{R}_{\mathbf{2}}=\mathrm{OCH}_{3}$ : Sinapic acid

Figure 4. Chemical structures of phenolic acids in oak wood [47-49].

Table 3. Phenolic acids in oak woods.

\begin{tabular}{cccccc}
\hline Compounds & Sample & $\boldsymbol{\lambda}$ (Max) & $\boldsymbol{M}_{\mathbf{W}}$ & $\begin{array}{c}\text { ESI-MS/MS } \\
\text { Prominent Ions (m/z) }\end{array}$ & References \\
\hline Gallic acid & \multicolumn{5}{c}{ Hydroxybenzoic Acids } \\
Gentisic acid & A, B, D-I & 270 & 170 & $169[\mathrm{M}-\mathrm{H}]^{-}, 154,125,81,79$ & {$[5,40,50-56]$} \\
$p$-Hydroxybenzoic acid & B & 340 & 154 & $153[\mathrm{M}-\mathrm{H}]^{-}, 109$ & {$[50]$} \\
Protocatechuic acid & A, B, H & 259,293 & 138 & $137[\mathrm{M}-\mathrm{H}]^{-}, 93$ & {$[55]$} \\
Syringic acid & B, D-I & 275 & 198 & $197[\mathrm{M}-\mathrm{H}]^{-}, 182,167,153,138$ & {$[40,50,55]$} \\
Vanillic acid & A, B, D-G, I & 260,291 & 168 & $167[\mathrm{M}-\mathrm{H}]^{-}, 152,123,108$ & {$[40,50]$} \\
$p$-Hydroxybenzoic aldehyde & B & 280,254 & 122 & $121[\mathrm{M}-\mathrm{H}]^{-}$ & {$[50]$} \\
Protocatechuic aldehyde & A, B, H & 280,310 & 138 & $137[\mathrm{M}-\mathrm{H}]^{-}$ & {$[40,50]$} \\
Syringaldehyde & A, C-I & 307 & 182 & $181[\mathrm{M}-\mathrm{H}]^{-}, 166,151$ & {$[40,51-57]$} \\
Vanillin & A-I & 304 & 152 & $151[\mathrm{M}-\mathrm{H}]^{-}, 136,108$ & {$[5,40,50-57]$} \\
\hline & & Hydroxycinnamic Acids & {$[40,50,54]$} \\
$p$-Coumaric acid & A, B, G & 310 & 164 & $163[\mathrm{M}-\mathrm{H}]^{-}, 119,94$ & {$[40,50]$} \\
Caffeic acid & A, B & 324 & 180 & $179[\mathrm{M}-\mathrm{H}]^{-}, 135$ & {$[5,40,50,53]$} \\
Ferulic acid & A, B, E, F & 280,340 & 194 & $193[\mathrm{M}-\mathrm{H}]^{-}, 178,149,134$ & {$[40,50]$} \\
Sinapic acid & A, B & 340 & 222 & $221[\mathrm{M}-\mathrm{H}]^{-}, 164,149,121$ & {$[5,40,51-53,56]$} \\
Sinapaldehyde & A, D-F, I & 254 & 208 & $207[\mathrm{M}-\mathrm{H}]^{-}, 192,189$ & {$[5,40,51-53,56]$} \\
Coniferaldehyde & A, D-F, I & 260 & 178 & $177[\mathrm{M}-\mathrm{H}]^{-}, 162,159,147$ & {$[51,52,54]$} \\
Eugenol & D, E, G & 230 & 164 & $163[\mathrm{M}-\mathrm{H}]^{-}, 149,137$ &
\end{tabular}

A: Toasted and non-toasted oak wood samples (American, French, Hungarian, Rumanian and Russian oak woods); B: Oak aged wine samples (American, French and Hungarian oak woods aged over 12 months); C: Oak wood samples; D: Oak aged sugarcane spirit samples; E: Green oak samples (Spanish oak wood); F: Natural seasoning and tasted oak wood samples (American, French and Spanish oak woods); G: Oak aged sugarcane spirit samples (Quercus spp. oak wood aged over 12 months); H: Oak aged rum samples (Oak wood aged over 15 years); and I: Oak chips samples (American oak wood).

Some studies have found that the color of red wines to be strongly influenced by the presence of phenolic acids [58]. These acids had an important function to enhance and stabilize the pigment of red wines by intra- and intermolecular copigmentation reactions, especially the hydroxycinnamic acids could provide approximately $60 \%$ to $70 \%$ color enhancement at $520 \mathrm{~nm}[59,60]$. Table 4 shows the copigmentation effects (bathochromic shift and hyperchromic effect) of the four hydroxycinnamic acids. 
Table 4. The compigmentation effects of cyanidin-3-O-glucoside (Cy-3-glu) and cyanidin-3-O-sophoroside (Cy-3-soph) with four hydroxycinnamic acids [61].

\begin{tabular}{cccccccccc}
\hline & & \multicolumn{3}{c}{ Hyperchromic Effect (\%) } & \multicolumn{3}{c}{ Bathochromic Shift $\left(\Delta \boldsymbol{\lambda}_{\text {max }}, \mathbf{n m}\right)$} \\
\cline { 3 - 10 } Anthocyanins & pH & $\begin{array}{c}\text { Coumaric } \\
\text { Acid }\end{array}$ & $\begin{array}{c}\text { Caffeic } \\
\text { Acid }\end{array}$ & $\begin{array}{c}\text { Ferulic } \\
\text { Acid }\end{array}$ & $\begin{array}{c}\text { Sinapic } \\
\text { Acid }\end{array}$ & $\begin{array}{c}\text { Coumaric } \\
\text { Acid }\end{array}$ & $\begin{array}{c}\text { Caffeic } \\
\text { Acid }\end{array}$ & $\begin{array}{c}\text { Ferulic } \\
\text { Acid }\end{array}$ & $\begin{array}{c}\text { Sinapic } \\
\text { Acid }\end{array}$ \\
\hline \multirow{2}{*}{ Cy-3-glu } & 3.2 & 11.6 & 18.8 & 25.3 & 29.7 & 2.5 & 4.5 & 6.6 & 8.7 \\
& 4.0 & 27.7 & 41.0 & 63.9 & 110.5 & 2.2 & 4.0 & 6.8 & 10.2 \\
\hline \multirow{2}{*}{ Cy-3-soph } & 3.2 & 9.9 & 11.2 & 16.5 & 23.9 & 2.5 & 3.8 & 5.2 & 5.5 \\
& 4.0 & 16.3 & 22.7 & 40.7 & 60.9 & 2.3 & 2.6 & 6.5 & 7.7 \\
\hline
\end{tabular}

\subsection{Ellagitannins}

Ellagitannins (Figure 5) constitute one of the major classes of polyhydroxyphenyl-bearing polyphenols derived from the secondary metabolism of plants. In oak, both sapwood and heartwood contained ellagitannins [62]. Their structures are characterized by one or more hexahydroxydiphenoyl (HHDP) moieties esterified with a sugar, typically D-glucopyranose [63]. HHDP moieties were further connected with neighboring galloyl residues through $\mathrm{C}-\mathrm{C}$ biaryl ether bonds as a result of phenolic oxidative coupling processes [64,65]. Ellagitannin compounds have an enormous structural variability because of the different linkages of HHDP residues with the glucose moiety and their strong tendency to form dimeric and oligomeric derivatives [65]. Monomeric vescalagin and castalagin (Figure 5a) are normally found in oak species used in barrel making, which largely predominate in oak wood representing $40 \%-60 \%$ of the ellagitannins [18]. Dimers (roburin A and roburin D, Figure 5b) and lyxose/xylose derivatives (grandinin, roburin B, roburin C, and roburin E, Figure 5c,d) are also identified in oak woods [66]. In addition, flavanols, including dihydroflavonols, often occur in association with ellagitannin to form flavano-ellagitannin derivatives (such as acutissimin A and acutissimin B, Figure 5e,f), detected in aged wine and whisky, and gallagyl-glucosides, whose structure has an ellagic acid moiety (punicalagin, peduncalagin, Figure 5g,h), also belong to the same group [39]. The level of their occurrence in the cooperage wood depended partly on the species used, as well as the type and length of drying and toasting $[67,68]$. Many distinctive properties of oak could be attributed to these ellagitannins. For example, ellagitannins are toxic to microorganisms, and could prevent the rapid decay of the wood [69]. Therefore, the relative abundance of ellagitannins in oak wood endows oak with good resistance to fungal degradation. The combined presence of ellagitannins and tyloses in oak heartwood has also made these woods unrivaled in the manufacturing of barrels used in wine and whiskey aging [70]. Both acutissimin A and acutissimin B have been reported to possess interesting biological properties such as antitumoral to inhibit human DNA topoisomerase II $\alpha$ in vitro [71]. Furthermore, ellagitannins could directly affect wine color. To the best of our knowledge, the reaction between ellagitannin and purple or red-colored grape-derived pigment could get furnished a novel orange-colored anthocyano-ellagitannin compound [72].

\subsection{Polyphenolic Compounds in Non-Oak Woods}

Although aging of wines were carried out solely and exclusively with oak wood, the dilemma of huge demand and limited resources required researchers to look for alternative species for coopering. 
In this process, the phenolic fraction was considered to be one of the most important parameter for evaluating quality in the choice of good alternative aging wood [73]. Research suggested that chestnut (Castanea sativa), acacia (Robinia pseudoacacia), cherry (Prunus avium), ash (Fraxinus excelsior and F. vulgaris) and mulberry (Morus alba and M. nigra) had been considered as possible sources of materials for cooperage to give a particular personality to aged wines and other derived products, such as cider, spirits and vinegar [74-76]. Some authors also highlighted that wines or vinegars aged in non-oak barrels had better organoleptic characteristics.

a

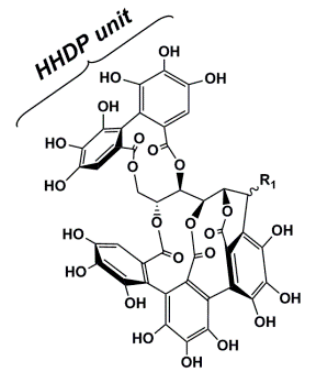

$R_{1}=\alpha-\mathrm{OH}$, castalagin

$R_{1}=\beta-O H$, vescalagin

C

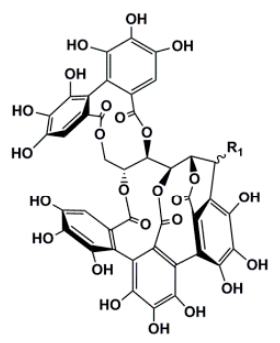

$R_{1}=$ lyxose, grandinin

$R_{1}=x y l o s e$, roburin $E$

e

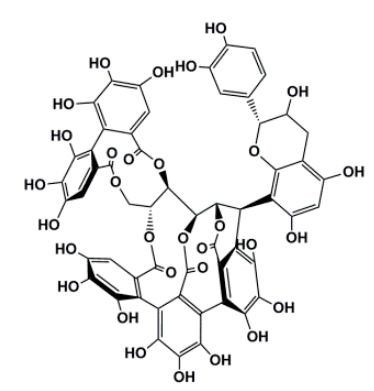

acutissimin A

g

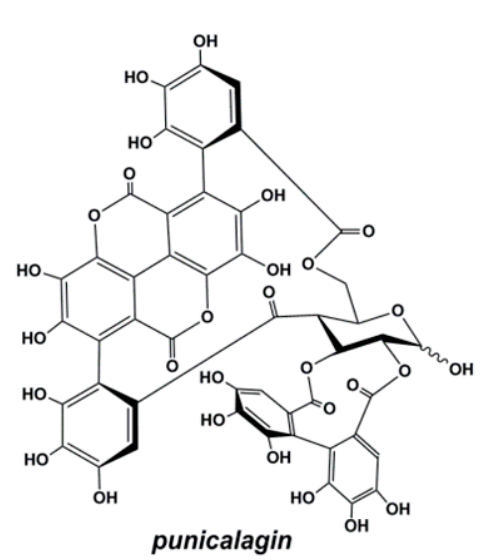

b

d

f

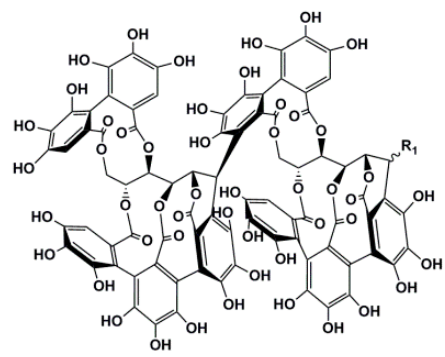

$R_{1}=\alpha-O H$, roburin $D$

$R_{1}=\beta-O H$, roburin $A$

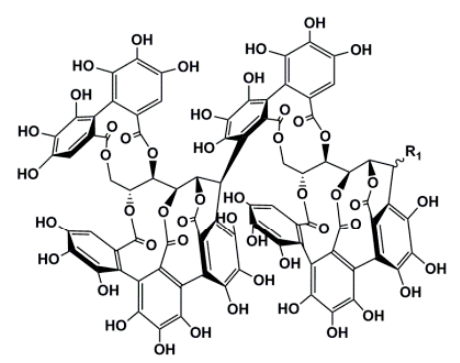

$R_{1}=$ lyxose, roburin $B$

$R_{1}=$ xylose, roburin $C$

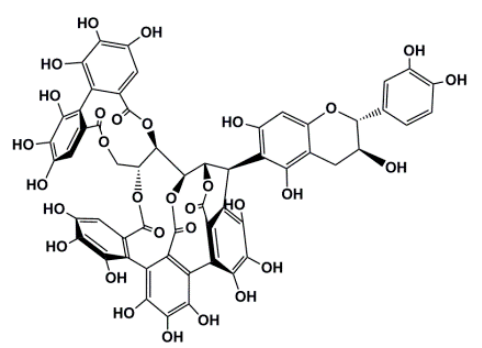

acutissimin B

h

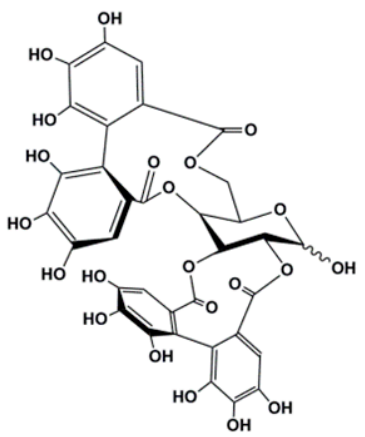

pedunculagin

Figure 5. Chemical structures of ellagitannins [18]. 
Chestnut wood was widely used for enological purposes in the Mediterranean region in the past. This was not only because they are especially rich in gallic acid and ellagitannins, but also because of their widespread availability and lower cost. Wines aged in chestnut wood contained high amounts of phenolic compounds, which could protect must from undesirable oxidation reactions, and stabilize the coloring compounds and improve the astringency of the wines [73]. Consequently, chestnut wood is the only alternative to oak that has been approved by the International Organization of Vine and Wine (OIV) for wine ageing. In recent years, there has been renewed interest in the phenolic composition of chestnut wood. Results revealed that its heartwood has the most similar polyphenolic profile to oak. However, there were also some differences. For example, 1-O-galloyl castalagin, which was for the first time found in chestnut samples, might originate from the esterification of castalagin or vescalagin with a gallic acid residue [77].

Some published work on the chemical composition of $R$. pseudoacacia wood, commonly known as false acacia, pointed out important chemical differences in relation to the oak wood that needs to be taken into account when considering that for cooperage [74]. Data in the literature showed that the acacia heartwood contained high amounts of flavonoids, dihydrorobinetin and robinetin, at the concentrations of up to $100 \mu \mathrm{mol} / \mathrm{g}$. These compounds are characteristic markers of acacia wood, since they have not been detected in other woods used for cooperage, such as oak, chestnut, cherry and mulberry [76]. In contrast to those sources, acacia has been found to have only a small amount of condensed tannins and no hydrolysable tannins. Moreover, the low molecular weight phenolic compounds with a $\beta$-resorcylic structure in both acid and aldehydic forms were different to other woods $[74,76]$.

Cherry wood is abundant in condensed tannins (procyanidin type). Additionally, some phenolic acids and their esterification products such as benzoic acid, $p$-hydroxybenzoic acid, 3,4,5-trimethylphenol, $p$-coumaric acid, methylsyringate and methylvanillate, and flavonoids such as naringenin, aromadendrin, isosakuranetin and taxifolin, could be used as its phenolic markers for authenticity purposes [75,78]. For ash wood, the presence of secoiridoids, phenylethanoid glycosides, or $d i$ - and oligolignols could be used as good identifiers [78]. According to the previous reports, mulberry could be identified by its high levels of polyphenols, in particular oxyresveratrol and its glycosides, as well as coumarin glycosides. However, although the different phenolic compounds can be used as characteristic markers to distinguish the type of wood, the polyphenolic profile variability of beverages such as wine and oak aged spirits, and their evolution during ageing, makes the analysis of the markers found in the wood more complex than for the woods themselves [79].

\section{Some Factors Affecting the Polyphenolic Profile of Oak Woods}

The concentration of polyphenolics extracted from wood into wines during aging mainly depends on the pool of these compounds present in the barrels' wood, as well as the aging conditions. Towey and Waterhouse [80] stated that the structures and amounts of polyphenolics could be affected by the species of the wood and other factors, including geographical origin [70,81-83], silvocultural treatment, drying treatment, degree of toasting [81,84], and the length of time wines spent in the barrels. In addition, barrel age and usage (i.e., the number of times a barrel was used) [85], and barrel volume also affected the polyphenol contents in wines. 


\subsection{Oak Species and Geographical Origins}

In the barrel industry, three wood sources are most frequently used: American white oak ( $Q$. alba) and two French red species ( $Q$. petraea and $Q$. robur). The major differences between these oak woods are as follows. American oak wood is characterized by a lower total ellagitannin and significantly higher quantities of vanillin content than the French oak. However, Q. robur had higher amounts of gallic, protocatechuic, caffeic, sinapic acids, and total phenolics compared with $Q$. alba $[7,86]$. Nonetheless, pedunculate $(Q$. robur) and sessile (Q. petraea) oaks were not significantly different in their ellagitannin content $[7,86,87]$. During oak harvest, French oak samples, from the Troncais and Vosges regions, were found to contain about twice of eugenol of American oak samples. However, after three years of open-air seasoning, the eugenol concentration of French oak samples decreased by $60 \%$ to $70 \%$, whereas the decrease in the American oak samples was minimal [88]. Interestingly, even within a single species, there was high variability in polyphenolic composition that has been recognized in French oak from different geographic regions. Oak wood from the southwest (e.g., Limousin), center (e.g., Troncais, Nevers, and Allier), and northeast (e.g., Vosges) of France could also be differentiated based on their differing vanillin and eugenol contents [89,90]. Prida and Puech studied 56 American oaks, 276 French oaks, and 102 Eastern European oak trees and found that ellagitannins were the best substances for distinguishing the species, whereas eugenol, 2-phenylethanol, and the phenolic aldehydes vanillin and syringaldehyde, which had higher concentrations in oak samples from Eastern Europe, were the best components to be used as variables for distinguishing geographic origins [91]. Several studies on the polyphenolic composition of Spanish oaks indicated that low molecular weight phenolic and tannic profiles of Spanish species were similar to those of French oak, and quantitative differences often decreased with seasoning and toasting processes [8,53]. Phenolic parameters and sensory analysis showed that wines aged with the Spanish $Q$. pyrenaica had enological characteristics similar to those aged in American or French oak wood using barrels, chips, or staves [22,92]. Researchers thus concluded that Spanish oak wood was a potential alternative to traditional oak species based on their phenolic compounds.

\subsection{Cooperage Treatment}

During barrel production, the oak wood used in cooperage undergoes several processing steps which affect the composition of the wood. Seasoning and toasting processes especially critically affected the polyphenol composition [81,84].

\subsubsection{Seasoning}

The natural seasoning of oak is more than a simple dehydration process. There is a loss of water soluble polyphenolic substances, which contributes to a decrease in the sensations of bitterness and astringency in wines [93]. During the seasoning treatment, the concentrations of different ellagitannins decreased according to the duration of this process, and this loss was predominant in the first few millimeters of each stave face over the first three years [8]. This decline was thought to be partly due to hydrolysis reactions. In contrast drying through outdoor, seasoning of oak increased the levels of volatile phenols and phenolic aldehydes, including eugenol, vanillin, syringaldehyde, coniferaldehyde, and 
sinapaldehyde, especially when seasoning was carried out in hot climates [50]. Simón et al. [94] analyzed four oak wood samples in Spain and concluded that the concentrations of polyphenolic compounds differed according to the seasoning time and species. Their research also showed that ellagic acid was the main component in unseasoned wood, followed by gallic acid. With respect to the remaining components, aldehyde levels were always higher than those of acids, and cinnamic compounds were more abundant than benzoic acids, except for ferulic acid, which was present at very low concentrations [84].

\subsubsection{Toasting}

Toasting, the next step of cooperage treatment, induces severe chemical modification to a range of compounds in the wood. The level of toasting is generally referred to in terms of light (toasting for 5 min to reach a temperature of $180^{\circ} \mathrm{C}$ ), medium (toasting for $35 \mathrm{~min}$ to reach a temperature on the wood surface of $160-170^{\circ} \mathrm{C}$ ), and heavy (toasting for $17.5 \mathrm{~min}$ to reach a temperature of $230^{\circ} \mathrm{C}$ ). During this process, a variety of hydrothermolysis and pyrolysis reactions takes place depending on the degree of toasting. Pyrolysis and hydrothermolysis degraded wood constituents to some extent, including not only the ellagitannins, which are readily hydrolyzed $[8,95,96]$, but also the lignin and hemicelluloses, which are subsequently altered. Lignin was a tridimensional polymer made up of two phenylpropanoid alcohols, namely, 4-hydroxy-3-methoxycinnamic alcohol (coniferyl alcohol) and 4-hydroxy-3,4dimethoxycinnamic alcohol (syringyl alcohol). In toasted wood, a variety of mono- and dimethoxylated phenols and high levels of cinnamic acids, benzoic acids, and aldehydes were formed from these two alcohols by hydrolytic and oxidative processes. The degradation of these compounds would contribute to increase the levels of phenolic aldehydes and other components in the wood with desirable sensory effects. In contrast, non-toasted oak wood only had a small quantity of volatile phenols, mainly eugenol, and traces of phenolic aldehydes [97,98]. Toasting also had an important influence on the ellagitannin compositions of the oak. Roburins A-E, grandinin, vescalagin, and castalagin decreased during this process [8]. An increase in the ellagic acid content of toasted samples was also observed, which might be due to the release of the compound by ellagitannins during thermal degradation [40]. French coopers had, perhaps, used toasting to lower the tannin level, thereby limiting the increase in a wine's astringency. Doussot et al. [68] found that medium toasting drastically enhanced the loss of ellagitannins $(>90 \%)$ but increased volatile phenols by $30 \%$. On the other hand, other phenolic compounds, such as gallic, protocatechuic, caffeic acids, and scopoletin, were also sensitive to thermal degradation, causing a significant decrease in their content in the toasted wood [99].

\subsubsection{Aging Process and Barrel Properties}

A series of chemical reactions occurs during barrel aging of wines. The length of time that a wine spends in a barrel and the barrel volume affects the polyphenolic content in wines. Sanza et al. [50] evaluated the aged wines treated under different systems (barrels, oak chips, and oak staves) and found an increase in the concentration of p-coumaric, ferulic, gallic, protocatechuic, caffeic acids, and protocatechuic aldehyde during aging. Several beverages, including cognac, whiskey, brandy, vinegar, mescal, and wine increased their antioxidant capacity as a result of wood contact [22]. This was due to the significant amount of polyphenols extracted by these beverages from the wood during aging. 
Therefore, the nature and content of polyphenolics of the wood used in aging could determine the increase in antioxidant capacity of wines during storage [100].

Once oak components were extracted out of wood, they underwent a series of micro-oxygenation alterations. Specifically, phenolic aldehydes could change to their respective acids with subsequent ethyl ester formation. Some winemakers also recommended that micro-oxygenation could be used as a complementary technique to oak aging when oak barrel alternatives were used. Pérez-Prieto et al. [101] studied wines matured in oak barrels of different capacities $(220,500$ and $1000 \mathrm{~L})$ and found that guaiacol and 4-methylguaiacol was extracted rapidly during the first several days of oak maturation. In contrast, vanillin required at least 3 months to accumulate in wines. However, contrary to these results, Spillman et al. [102] found that the rate of vanillin extraction was very fast during the first two weeks of oak storage in a hydroalcoholic medium. The volatile phenols 4-ethylphenol and 4-ethylguaiacol were formed in large quantities after the first 90 days of oak maturation. These findings were in agreement with the results obtained by Pérez-Prieto et al. [101]. Wines matured in $1000 \mathrm{~L}$ oak barrels accumulated the least amounts of volatile compounds. Rodríguez-Rodríguez et al. [103] also compared the wines in different volumes ( 300 and $500 \mathrm{~L}$ ) of French oak barrels and found that wines aged in the smaller barrel with a medium toast level acquire better chromatic characteristics, higher amounts of oak-related aroma compounds, and higher sensory analysis scores.

\subsubsection{Others}

Other factors might also affect the polyphenol contents of oak, such as the soil type, sun exposure, and rainfall where the oak trees were cultivated. Many authors have reported a decline in soluble ellagitannins with increasing heartwood age [104]. This decline was believed to be partly due to hydrolysis reactions and mostly due to non-enzymatic oxidative polymerization reactions, which might reduce tannin solubility [105,106]. Mosedale et al. [107] found no difference in the heartwood ellagitannin content when clonal and progeny trials of oaks ( $Q$. petraea and $Q$. robur) were analyzed.

\section{Analysis of Polyphenolics in Oak Woods}

With the advent of the modern scientific revolution and the development of chemistry from alchemy, plant polyphenols became some of the first subjects of scientific researches. Many research worked in this field and provided the first results in relation to the quantitative and qualitative analyses of polyphenolic compounds [39]. Given the large number and the chemical complexity of these polyphenolics, considerable progress in terms of extraction methods and analytical techniques have been made, especially over the last few decades. Different analytical methods, such as stir bar sorptive extraction, solid phase microextraction (SPME), and high performance liquid chromatography (HPLC), have been studied and described. The characterization of polyphenolic compounds relied on the suitability of these methods for the analysis of plant tissues. The next section summarizes the analytical chemistry applications and tools currently used to analyze polyphenolics in oak wood, and other sources, with similar polyphenolic composition. Table 5 lists representative examples of the methods used for separation of (poly)phenols. 
Table 5. Overview on methods for analysis of (poly)phenolics from oak woods and other different sources.

\begin{tabular}{|c|c|c|c|c|}
\hline Source & Sample Preparation & Analytical Techniques & Main Polyphenolic Compounds & References \\
\hline Oak heartwood (2006) & $\begin{array}{c}\text { Extracted sawdust with } \\
\text { methanol/water (1:1); Filtration and } \\
\text { evaporated; Residue extracted in } \\
\text { diethyl ether and ethyl acetate }\end{array}$ & HPLC-DAD & $\begin{array}{c}\text { Gallic acid, vanillic acid, vanillin, syringic acid, } \\
\text { syringaldehyde, ellagic acid, coniferylaldehyde, } \\
\text { sinapic aldehyde, scopoletin, castalagin, vescalagin, } \\
\text { grandinin, roburin A-E }\end{array}$ & [52] \\
\hline $\begin{array}{l}\text { Oak and Brazilian woods } \\
\qquad(2009)\end{array}$ & $\begin{array}{l}\text { Extracted sawdust with sugarcane } \\
\text { ethanol }(47 \% v / v) \text {, followed by } \\
\text { separation using C18 Sep-Pak }\end{array}$ & $\begin{array}{l}\text { HPLC-DAD- } \\
\text { fluorescence and } \\
\text { HPLC-ESI-MS }\end{array}$ & $\begin{array}{l}\text { (+)-Catechin, coniferaldehyde, coumarin, ellagic acid, } \\
(-) \text {-epicatechin, eugenol, gallic acid, myricetin, } \\
\text { quercetin, scopoletin, synapaldehyde, syringaldehyde, } \\
\text { syringic acid, trans-resveratrol, vanillic acid, vanillin }\end{array}$ & [51] \\
\hline Oak heartwood (2011) & $\begin{array}{c}\text { Extracted sawdust with } \\
\text { methanol/water (1:1); Filtration and } \\
\text { evaporated; Residue extracted in } \\
\text { diethyl ether and ethyl acetate }\end{array}$ & HPLC-DAD & $\begin{array}{l}\text { Gallic acids, ellagic acids, vanillic acids, syringic } \\
\text { acids, ferulic acids, vanillin, syringaldehyde, } \\
\text { coniferaldehyde, sinapaldehyde, aesculetin, scopoletin }\end{array}$ & [53] \\
\hline Oak heartwood (2011) & $\begin{array}{c}\text { Extracted sawdust with } \\
\text { methanol/water (1:1); Filtrated and } \\
\text { evaporated; Residue extracted in } \\
\text { diethyl ether and ethyl acetate }\end{array}$ & HPLC & Roburins A-E, grandinin, vescalagin, castalagin & [8] \\
\hline Cherry heartwood (2010) & $\begin{array}{c}\text { Extracted sawdust with } \\
\text { methanol/water (1:1); Filtrated and } \\
\text { evaporated; Residue extracted in } \\
\text { diethyl ether and ethyl acetate }\end{array}$ & $\begin{array}{c}\text { HPLC-DAD/ } \\
\text { ESI-MS }\end{array}$ & $\begin{array}{l}\text { Gallic acid, protocatechuic acid, vanillic acid, vanillin, } \\
\text { syringic acid, syringaldehyde, 3,4,5-trimethoxyphenol, } \\
\text { protocatechualdehyde, benzoic acid, } p \text {-hydroxybenzoic } \\
\text { acid, } p \text {-coumaric acid, scopoletin, coniferaldehyde, } \\
\text { coniferaldehyde, methyl vanillate, methyl syringate }\end{array}$ & [108] \\
\hline Black pine bark (2010) & $\begin{array}{l}\text { Extracted with pressurized hot water; } \\
\text { Filtrated; Washed with chloroform, } \\
\text { ethyl ether and other solvents }\end{array}$ & $\begin{array}{c}\text { HPLC, CC, TLC and } \\
\text { FT-NMR }\end{array}$ & $(+)$-Catechin, $(-)$-epicatechin, quercetin, ferulic acid & [109] \\
\hline
\end{tabular}


Table 5. Cont.

\begin{tabular}{|c|c|c|c|c|}
\hline Source & Sample Preparation & Analytical Techniques & Main Polyphenolic Compounds & References \\
\hline Acacia heartwood (2011) & $\begin{array}{l}\text { Extracted sawdust with } \\
\text { methanol/water }(1: 1) ; \text { Followed by } \\
\text { extraction with ethyl acetate }\end{array}$ & $\begin{array}{c}\text { HPLC-DAD and } \\
\text { LC-DAD/ESI-MS/MS }\end{array}$ & $\begin{array}{l}\text { Gallic acid, gallic aldehyde, protocatechualdehyde, } \\
\text { methyl gallate, } \beta \text {-resorcilyc acid, vanillic acid, } \\
\beta \text {-resorcilyc aldehyde, caffeic acid, vanillin, } \\
\text { syringic acid, syringaldehyde, coniferaldehyde, } \\
\text { sinapaldehyde, ellagic acid, robtin etc. }\end{array}$ & [110] \\
\hline Red wine (2008) & Solid phase extraction & HPLC-UV & $\begin{array}{l}\text { Monomeric, oligomeric and polymeric } \\
\text { polyphenolic compounds }\end{array}$ & [111] \\
\hline $\begin{array}{l}\text { Red wine vinegar } \\
\text { produced in barrels made } \\
\text { from different woods } \\
\text { (2008) }\end{array}$ & Direct injected & HPLC-UV & $\begin{array}{l}\text { Gallic acid, protocatechuic acid, tyrosol, } \\
\text { caftaric acid, vanillic acid, }(+) \text {-catechin, caffeic acid, } \\
\text { syringic acid, }(-) \text {-epicatechin, } \\
\text { resveratrol glucoside, ellagic acid }\end{array}$ & [112] \\
\hline Vinegar (2012) & $\begin{array}{l}\text { Extraction of vinegar with stir bar at } \\
1250 \mathrm{rpm}, 25^{\circ} \mathrm{C} \text { for } 120 \mathrm{~min}\end{array}$ & GC-MS & $\begin{array}{c}\text { Benzaldehyde, benzaldehyde, phenol, } \\
\text { 4-acetyl-2-methylphenol, 4-acetyl-2-methylphenol, } \\
\text { p-ethylguaiacol, 4-ethylphenol, 2,4-ditertbutylphenol, } \\
\text { benzoic acid }\end{array}$ & [113] \\
\hline $\begin{array}{l}\text { Pomegranate beverage } \\
\text { (2012) }\end{array}$ & Direct injection & HPLC-DAD-MS & $\begin{array}{l}\text { Gallic acid, }(+) \text {-catechin, }(-) \text {-epicatechin, caftaric acid, } \\
\text { ellagic acid, myricetin, quercetin, etc. }\end{array}$ & [114] \\
\hline Apple pomace (2009) & $\begin{array}{l}\text { Extracted apple pomace powder with } \\
\text { ethanol; Concentrated and vacuum } \\
\text { dried; fractionated polyphenols using } \\
\text { Sephadex LH-20; HSCCC separation }\end{array}$ & HPLC-MS & $\begin{array}{l}\text { Chlorogenic acid, quercetin-3-glucoside, phloridzin, } \\
\text { quercetin-3-glacaside, quercetin-3-xyloside, } \\
\text { quercetin-3-arabinoside and quercetin-3-rhamnoside }\end{array}$ & [115] \\
\hline Apple pomace (2010) & $\begin{array}{l}\text { Extracted with ethanol and assisted } \\
\text { by microwave treatment }\end{array}$ & HPLC-UV & $\begin{array}{c}\text { Chlorogenic acid, cafeic acid, syrigin, (-)-epicatechin, } \\
\text { procyanidin B2, cinnamic acid, coumaric acid, } \\
\text { phlorizin, quercetin }\end{array}$ & [116] \\
\hline Onion (2008) & Extract with $80 \%$ methanol; Filtrated & HPLC-UV & $\begin{array}{l}\text { Kaempferol, quercetin, isoquercetin, quercetin } \\
\text { monoglucoside, quercetin diglucoside }\end{array}$ & [117] \\
\hline
\end{tabular}


Table 5. Cont

\begin{tabular}{|c|c|c|c|c|}
\hline Source & Sample Preparation & Analytical Techniques & Main Polyphenolic Compounds & References \\
\hline Onion (2009) & $\begin{array}{l}\text { Extracted with methanol:formic } \\
\text { acid:water }(50: 5: 45)\end{array}$ & HPLC-DAD & $\begin{array}{l}\text { Quercetin-3,4'-diglucoside, quercetin-4'-glucoside, } \\
\text { cyanidin-3-glucoside, cyanidin-3-laminaribioside, } \\
\text { cyanidin-3-(6"-malonyl-glucoside), } \\
\text { cyanidin-3-(6"-malonyl-laminaribioside) }\end{array}$ & [118] \\
\hline Onion (2010) & $\begin{array}{l}\text { Extracted with methanol:formic } \\
\text { acid:water (50:5:45) }\end{array}$ & HPLC-DAD & $\begin{array}{l}\text { Quercetin-3-glucoside, quercetin-3,4'-diglucoside, } \\
\text { quercetin-4'-glucoside, quercetin-7,4-diglucoside, } \\
\text { isorhamnetin-4-glucoside, isorhamnetin-3,4- } \\
\text { diglucoside, cyanidin-3-glucoside, cyanidin-3- } \\
\text { laminaribioside, cyanidin-3-(6"-malonyl-glucoside), } \\
\text { cyanidin-3-(6"-malonyl-laminaribioside) }\end{array}$ & [119] \\
\hline $\begin{array}{l}\text { Roasted wheat germ } \\
\text { (2009) }\end{array}$ & $\begin{array}{l}\text { Supercritical carbon } \\
\text { dioxide extraction }\end{array}$ & HPLC-MS & Ferulic acid, vanillic acid & [120] \\
\hline Pistachio (2010) & $\begin{array}{l}\text { Extracted crushed seeds and skins } \\
\text { with methanol/water }(2: 1) ; \\
\text { ultrasonicated; Homogenate } \\
\text { centrifuged and separated }\end{array}$ & HPLC-DAD & $\begin{array}{c}\text { Gallic acid, eriodictyol-7- } O \text {-glucoside, catechin, } \\
\text { naringenin-7- } O \text {-neohesperidoside, } \\
\text { quercetin-3- } O \text {-rutinoside, eriodictyol }\end{array}$ & [121] \\
\hline Potato peels (2011) & $\begin{array}{c}\text { Peels lyophilized and ground; } \\
\text { Extracted with methanol assisted by } \\
\text { microwave treatment }\end{array}$ & HPLC-UV & Chlorogenic acid, caffeic acid, ferulic acid, rutin & [122] \\
\hline Apple Seeds (2012) & $\begin{array}{l}\text { Extraction of defatted apple seeds } \\
\text { with aqueous acetone }(30: 70 ; v / v)\end{array}$ & HPLC-DAD & $\begin{array}{l}\text { Phenolic acids, chlorogenic acid, phloridzin, } \\
\text { phloretin-2'-xyloglucoside, flavan-3-ols, } \\
\text { quercetin-3-O-glucoside }\end{array}$ & [123] \\
\hline Rooibos (2011) & $\begin{array}{l}\text { Extraction with distilled water; } \\
\text { Followed by filtration and } \\
\text { re-extraction with ethanol }(80 \% ; v / v)\end{array}$ & HPLC-ESI-MS & $\begin{array}{l}\text { Esculin, rutin, quercetin, isoquercitrin, luteolin, } \\
\text { nothofagin, secoisolariciresinol, etc. }\end{array}$ & [124] \\
\hline
\end{tabular}


Table 5. Cont.

\begin{tabular}{|c|c|c|c|c|}
\hline Source & Sample Preparation & Analytical Techniques & Main Polyphenolic Compounds & References \\
\hline Rooibos (2012) & $\begin{array}{l}\text { Extraction with boiled deionized } \\
\text { water; Then filtrated }\end{array}$ & HPLC-DAD & $\begin{array}{l}\text { Phenylpyruvic acid-2-O-glucoside, } \\
\text { isoorientin, orientin, aspalathin, ferulic acid, } \\
\text { quercetin-3-O-robinobioside, vitexin, hyperoside, } \\
\text { rutin, isovitexin, isoquercitrin, nothofagin }\end{array}$ & [125] \\
\hline Mate tea (2012) & $\begin{array}{l}\text { Extraction of leaves with ethanol/water; } \\
\text { Followed by filtration }\end{array}$ & HPLC-DAD & Chlorogenic acid & [126] \\
\hline $\begin{array}{l}\text { Grapes (V. vinifera L.) } \\
\text { (2012) }\end{array}$ & SPME & GC-MS & $\begin{array}{l}\text { Phenol, 2-methylphenol, eugenol, } \\
\text { 2-methoxy-4-vinylphenol }\end{array}$ & {$[127]$} \\
\hline Mango (2012) & $\begin{array}{l}\text { Extraction with } 80 \% \text { methanol and } \\
2 \% \text { formic acid; Followed by } \\
\text { extraction with } 80 \% \text { methanol }\end{array}$ & $\begin{array}{l}\text { HPLC-DAD-MS/ } \\
\text { MS-ESI }\end{array}$ & $\begin{array}{l}\text { Gallic acid, protocatechuic acid, } \\
\text { chlorogenic acid, vanillic acid }\end{array}$ & [128] \\
\hline Olive oil (2012) & $\begin{array}{l}\text { Extraction with } n \text {-hexane and } \\
\text { assisted with an ultrasonic probe; } \\
\text { Centrifugation and separation; } \\
\text { Followed by extraction with methanol }\end{array}$ & $\begin{array}{l}\text { HPLC-DAD-FLD and } \\
\text { LC-MS }\end{array}$ & $\begin{array}{c}\text { Hydroxytyrosol, tyrosol, oleuropein aglycone } \\
\text { derivative and ligstroside derivative }\end{array}$ & [129] \\
\hline
\end{tabular}




\subsection{Extraction}

The range of phenolic compounds extracted from plant materials is influenced by the chemical nature of the compounds, the extraction method used, the sample particle size, the extraction time and conditions, and the presence of interfering substances. Phenolic extracts of plant materials are composed of a mixture of different classes of phenolics determined by their solubility in the solvent system used [130,131]. Although the plant matrices are various, surprising similarity in the extraction systems could be observed in extracting polyphenols and their derivatives. Methanol, ethanol, acetone, water, ethyl acetate, and, to a lesser extent, propanol, dimethylformamide, and their combinations were frequently used to extract polyphenolics [132]. Non-polar organic solvents (i.e., $n$-hexane, petroleum ether, chloroform, and dichloromethane) have relatively low extraction abilities for polyphenols, and were usually used in sample treatment to remove lipids and chlorophyll and/or to prevent enzymatic reactions [41]. Moreover, given that some extracted phenols were present as glycosides, caution was exercised in extracting them to avoid hydrolysis, since alkaline hydrolysis might lead to significant losses of hydroxycinnamic acid derivatives [133]. Precautionary techniques, including isolation in the dark and under cold conditions were performed. Some extraction methods also used small amounts of ascorbic acid to avoid the polyphenol oxidase reaction and protect degradation of phenolic compounds $[134,135]$.

Soluble phenolic compounds can be easily isolated from plant tissues by extraction with methanol or methanol acidified with $0.1 \%(v / v) \mathrm{HCl}$. Methanol/water $(1: 1)$ for example has been widely used to extract low molecular weight phenolic compounds (hydroxybenzoic and hydroxycinnamic acids) in oak wood at room temperature for $24 \mathrm{~h}$ [5], and absolute methanol/HCl mixtures was used to extract ellagitannins. However the latter solvent was more effective than the simple methanol/water solution [50]. In addition, the water and organic solvents used individually or in mixture, such as acetone/water/acetic acid (90/9.5/0.5) and ethyl acetate/methanol/water (60/30/10), significantly affected the total polyphenol contents extracted from Q. coccifera [136].

Besides the traditional solvent reflux extraction, supercritical fluid extraction, ultrasound extraction, and microwave extraction were favored alternative extraction methods compared with the first method because of their high efficiency and low solvent consumption. In some studies, the authors described an increase in total polyphenols by ultrasound $[137,138]$. This observed increase was attributed to the phenomenon of cavitation produced in the solvent by the passage of an ultrasonic wave, which accelerated the transfer of organic substances from plant materials. SPME, a relatively new extraction method, was another alternative to the aforementioned techniques because it was simple, rapid, and inexpensive. This technique does not require solvents, thereby reducing sample manipulation, and is easy to automate [139]. However, SPME was only used to determine a wide variety of volatile phenolic compounds with low molecular weight in oak products or oak-aged wines. For example, Díaz-Maroto et al. [140] used a Head Space-SPME (HS-SPME) method to rapidly extract volatile compounds (e.g., eugenol, vanillin, and syringaldehyde) from wines present in non-toasted and toasted oak wood of different origins.

In addition, with the development of science and technology, some new technologies and new methods have been applied to extract the polyphenolic compounds. Kadim et al. studied the mechanism and the kinetics of phenolic extraction from woods to wines during aging in barrels and found that the 
mass transfer rate was controlled by the rate of liquid penetration into the wood, rather than by diffusional transport of the phenolics [141]. Based on this finding, they developed a mathematical model to represent this migration, which satisfactorily predicted the shape of the extraction curve in the case of white wine aged in new barrels.

\subsection{Separation}

Phenolic extracts, first concentrated under vacuum, could be further extracted with petroleum ether, ethyl acetate, or diethyl ether to remove lipids and other unwanted foreign substances. Then, a variety of separation and identification methods could be used to characterize the phenolic compounds in them. The frequently used methods for separation and purification of polyphenols were various chromatographic methods, including paper chromatography (PC), thin layer chromatography (TLC), column chromatography (CC), HPLC, countercurrent chromatography (CCC) and some further developed methods.

$\mathrm{PC}$, as an old analytical method that separated and identified mixtures, used to be very popular in the 1950s. During that time, many publications attested to the utility of this technique in the analysis of phenolic substances. For example, Bate-Smith separated anthocyanins, flavones, and other polyphenolic substances by using a butanol/acetic acid/water system [142]. Evaris et al. used butane/pyridine/aqueous sodium chloride and diazotized sulfanilic acid to separate and detect simple phenols and their derived phenolic acids [142]. Lindstedt applied PC to the separation and identification of nine phenolic constituents of pine heartwood extracts and found that the best results could be obtained with a water-saturated mixture of benzene and ligroin containing traces of methanol [143]. Quinn and Singleton [144] used 2D PC to analyze aqueous ethanolic extracts of three sources of oak woods. Ellagitannins have been identified in all oak wood extracts by using paper chromatographic $R f$ values. Although the PC method has largely been replaced by TLC, it is still a powerful tool.

TLC was also another chromatographic technique used to separate the mixtures. Generally, it was performed on a sheet of glass, plastic, or aluminum foil, which was coated with a thin layer of adsorbent material, usually silica gel, aluminum oxide, or cellulose (blotting paper) [145]. Lepri et al. [146] described the application of TLC to polyhydroxybenzenes and dichloro-, trichloro-, dinitro- and alkylphenols by using water/alcohol mixtures and silanized silica gel as the stationary phase. The polarity and strength, and hence $\mathrm{pH}$, of the solvents used in the mobile phase could be varied depending on the separation method to obtain the desired effect. For instance, it was possible by varying the strength of the solvent system, such as $5 \%$ acetic acid or pure water, to better separate $d i$ - and tri-glycosides of flavonoids. In contrast, aglycones and monoglycosides were better resolved in $40 \%$ to $50 \%$ acetic acid. Once an appropriate separation method was applied and the stationary phase was dry, the separated compounds could be further analyzed by using visible light (chalcones) or UV (flavonoids, phenols, and hydrolyzable tannins). When phenolics after spray reagent treatment, were examined under daylight or UV, the colors could be used to identify their classes, since phenols usually showed blue, green, brown, and red colors, whereas flavonoids usually showed orange, yellow, and green hues. Some preliminary structural elucidation of phenolics could also be determined based on their fluorescent color under UV. Flavonoids, for example, range from dark purple (5,4'-OH flavones/flavonols with no free 3,3'- or 5'-OH) to dull yellow (flavonol aglycones) [147]. However, the yield from TLC plates was small, thus it was often used to analyze and identify samples, but not to separate them for the preparation of samples. 
HPLC could be used to separate polyphenols in a liquid mixture. It was worth noting that this method was not bound by sample volatility or thermal stability, and could be conducted at room temperature, was easy to use, and generated powerful data. HPLC separation of phenolics could be classified into two groups: (1) Non-polar phenolics (separating well on silica columns with an isocratic elution); and (2) Polar phenolics (separating well on reverse-phase chemically bonded silica columns with gradient elution). Ordinarily, monomeric phenolics were most often identified and characterized by using reverse-phase HPLC, using a gradient solvent system with at least one acidic solvent to elute the compounds according to their ionic properties [148]. In grapes and wines, where some phenolic compounds are often found in highly polymerized forms, acid-induced depolymerization in the presence of a nucleophile, such as thiol or phloroglucinol, must be performed first. The subunit profiles and the mean degree of polymerization of the sample could then be determined [149]. Normal phase HPLC was used to estimate the size of polymeric phenols of up to seven units in length. The method developed by Kennedy and Waterhouse allowed the determination of low- and high-molecular weight polymers, as well as low- and high-molecular weight colored polymers or pigments [150]. However, this method was not commonly used during sample preparation because of equipment constraints and low yield. Altogether, HPLC is presently the most widely used quantification method [151-153].

$\mathrm{CC}$ was often used for the separation and purification of natural phenols. Alumina was previously the main packing material of $\mathrm{CC}$, whereas resins and gels are more normally used today. Hathway used Solka Floc cellulose columns $(60 \mathrm{~cm} \times 5 \mathrm{~cm})$ for the fractionation of tannins from oak bark pulps. An aqueous solution $(125 \mathrm{~mL})$ containing water-soluble phenolics was applied to the top of the column, from which the sugars and mobile phenolics were eluted with $5 \mathrm{~L}$ of $10 \%(v / v)$ formic acid [154]. Oak bark phlobatannin occupied a zone stretching from 2.5 to $7.5 \mathrm{~cm}$ from the top of the column. Better results might be obtained by vinyl polymer gels, such as Toyopearl and Diaion [14,155], and hydroxypro-pylated dextran gel (i.e., Sephadex LH-20) [41]. Vidal et al. used a Toyopearl (TSK HW-50 column, $50 \mathrm{~cm} \times 25 \mathrm{~cm}$ ) equilibrated with water for a semi-preparative separation of anthocyanins extracted from grape skin with ethanol-water $(75: 25, v / v)$ containing $2 \%$ acetic acid. The condensed tannins are commonly separated by using Sephadex LH-20 CC. The crude extract was applied to the column and washed with ethanol to elute the non-tannin substances. Then, condensed tannins were eluted with acetone-water or alcohol-water [130,156].

$\mathrm{CCC}$ was recently explored as an alternative to liquid chromatographic techniques for the fractionation of various classes of phenolic compounds [130]. It uses an automated version of liquid-liquid separation, comparable with the repeated partitioning of an analyte between two immiscible phases by vigorous mixing in a separatory funnel. This technique is normally referred to as high-speed CCC (HSCCC). Regalado et al. used HSCCC for the preparative isolation of phenolic compounds in aged rum with a coil speed of $900 \mathrm{rpm}$. Solvent systems of $n$-hexane/ethyl acetate/methanol/water with $0.1 \%$ trifiuoroacetic acid $(1: 1: 1: 1(v / v / v / v))$ were used at a flow rate of $3 \mathrm{~mL} / \mathrm{min}$ for the elution of phenolics in ascendant and descendant modes [55].

\subsection{Identification}

Almost every established method for polyphenolic identification usually has its limitations. The gold standard for structural identification of any organic compound was NMR spectroscopy [157]. This 
powerful technique allowed the structures of unknown molecules to be deduced with little prior information required. For example, Sudjaroen et al. used methanol as an extraction reagent to isolate polyphenolic components from Longan (Dimocarpus longan Lour) seeds followed by by ${ }^{1} \mathrm{H}$ and ${ }^{13} \mathrm{C}$ NMR for identification. The technique successfully identified five main compounds, including ellagitannin corilagin, chebulagic acid, ellagic acid 4- $O-\alpha$-L-arabinofuranoside, isomallotinic acid, and geraniin [158]. Vivas et al. [159] applied NMR to elucidate that the two principal HHDP esters of ellagitannins in $Q$. robur heartwood were vescalagin and castalagin. The only limiting factor to NMR application was the requirement of relatively large amounts of the very pure samples, as well as its relatively high expense.

Mabry et al. introduced an alternative method based on UV-vis spectroscopy [160]. By obtaining spectra of hundreds of phenolics and their derivatives, many strong correlations were found between the chemical structures and their UV absorption characteristics. Generally, non-flavonoid and gallotannins had a characteristic peak at $280 \mathrm{~nm}$, ellagitannins had a UV spectra below $270 \mathrm{~nm}$, flavonoids, such as quercetin, absorbed maximally at $365 \mathrm{~nm}$, and anthocyanins were easily distinguished by measurement at around $520 \mathrm{~nm}$. For isomers, UV-vis spectral information alone could not be used for positive identification because co-eluting isomers could lead to spectra representing a mixture of the isomers. In this case, and for compounds with unavailable standards, additional means of identification should be used to interpret the separation, such as HPLC with a diode array detector (DAD) or mass spectrometry (MS) [28]. These methods are much simpler and easier than NMR, and the preliminary identification could be made without standards according to the literature. Besides, HPLC coupled with atmospheric pressure electrospray ionization (ESI)-ion trap mass spectrometry (ITMS) or triple quadrupole mass spectrometry (QQQ-MS) was one of the most widely used analytical techniques for targeted quantitative analysis of small molecules commonly found in analytic chemistry fluids. A less commonly used means of detection involves electrochemical and fluorescence detectors coupled to HPLC [142]. Cadahía and Simónet et al. determined the structures of several ellagitannins isolated from Spanish, French, and American oak woods by HPLC [8,52]. These compounds included roburins A-E, grandinin, vescalagin, and castalagin. The evolution of low molecular weight polyphenols in Spanish oak heartwood of $Q$. robur, $Q$. petraea, $Q$. pyrenaica, and $Q$. faginea, in relation to the processing of wood in barrel cooperage, was studied by HPLC [72]. In addition, the detection, using HPLC and MS in the positive mode, of flavonol glycosides in Picea and Abiess pecies, which belong to Pinaceae, have also been recorded [161]. About six 3-(6-acetyl-glucosides) and other acetyl-glucosides were identified. The most abundant sugar-moieties connected to the flavonoids were glucose and rutinose. Among them, the flavonol-rhamnosides were present only in the Abies species. However, these methods could only provide rapid access to compound molecular weight and sugar chain information. Spectral characteristics and mass information cannot precisely determine the structure of polyphenols. Combination with other means of identification, such as NMR, was still necessary to further explore the type and position of glycosidic bonds in polyphenolics.

\section{Polyphenol Bioactive Ingredients in Other Plant Foods}

Polyphenolic compounds are a group of biologically active molecules present extensively as metabolites in plants, which could be found in every part of fruits and vegetables mostly in the form of 
complex mixtures. Meanwhile, the varieties and contents of polyphenols in plants vary a lot depending on genotypes, species, environmental conditions, agronomic practices and the degree of maturity, etc. [162]. Some previous studies indicated that there were around 8000 kinds of polyphenols in plants while new polyphenols were discovered constantly. The characteristic phenols are various in different plants [163]. For instance, the primary polyphenols in strawberries (Fragaria ananassa Duch.), apples (Malus pumila Mill.), walnuts (Juglans regia L.), mangos (Mangifera indica L.), grapes (Vitis vinifera L.), and persimmons (Diospyros kaki L.) are respectively proanthocyanidins [164,165], phlorizin [166,167], juglone [168,169], mangiferin [170,171], resveratrols [172,173], and tannins [174,175]. These polyphenolic compounds in different plants could be used as the characteristic phenols to distinguish themselves or their nutritive values. For example, the astringency of persimmons is mainly caused by tannins; a large amount of lignins make the shell of the nuts hard; and resveratrols could be used as an indicator to identify the place of origin and raw materials of wine, as some species of grapes contain resveratrols.

With the improvement in people' living standards and the enhancement in consumers' health-care awareness, more and more research on the physiological functions of plant-derived polyphenols have received considerable attentions as potentially protective factors against cancer [176-178] and heart diseases [179] in part because of their potent antioxidative properties and their ubiquity in a wide range of commonly consumed foods of plant origin. Among other secondary plant metabolites, polyphenols are believed to contribute to the health protective effect of many food commodities. Therefore, they have even been named "vitamins of the 21st century" [180]. Yamanaka et al. reported that guava (Psidium guajava L.) leaf showed strong depression effect against Vibrio and Aeromonas species [181]. They analyzed the components of guava leaf drinks using HPLC-DAD and found that the drinks contained several kinds of tannins and polyphenolic compounds. After further separating the polyphenolic compounds, they discovered that ellagic acids, castalagin and casuarinin showed strong inhibitory effect against Vibrio and Aeromonas. As the major wintering fruits in the Mediterranean region, citrus fruits contain large amounts of flavonoids. Studies showed that they had high antioxidant activity which was of great help to replenish human body with antioxidant to fight against the damage caused by free radicals. Therefore, flavonoids become a major source of important nutrients for people living within this region [182]. In Finland, apples and onions are the main sources of dietary flavonoids that are highly antioxidative [183]. Moreover, the contents of dietary flavonoids and the antioxidant activity are concentration-dependent $[184,185]$. Fresh wine shows a unique nutritive value because it contains a lot of polyphenols and high antioxidant activity [186,187]. Raspberry (Rubus corchorifolius L.) seed polyphenols are effective antioxidants $[188,189]$. In the United States, polyphenols provided by apples account for $33 \%$ of the total phenolic content contained in all the fruits consumed [190,191]. They are the main source of dietary polyphenols. In addition, the antioxidant capacity of strawberries, blueberries (Vaccinium spp.), cranberries ( . macrocarpon L.) and other berries have been verified in vivo, in vitro and in clinical studies [192-195]. More than that, it has also been found that the antioxidant mechanism can effectively prevent the occurrence of cardiovascular diseases. In recent years, many researchers have found that the polyphenols in apples are also highly antioxidative with the functions of antisepsis, inflammation decrease, prevention of coronary heart disease, anti-tumor as well as many other pharmacological functions [196]. Furthermore, Some literatrues reported that cocoa polyphenols could inhibit cytokinin-induced $\mathrm{T}$ cell proliferation and prevent the excessive production 
of B cells through inhibiting the expression of IL-2mRNA and the generation of IL-2 secretions, indicating that polyphenols have certain immunomodulatory effects $[197,198]$.

\section{Conclusions}

Plant phenolics are secondary metabolites that constitute one of the most common and widespread group of substances in plants. To date, plant polyphenols are considered to present a large and diverse array of beneficial effects on both plants and humans. This study presents an overview of oak polyphenols and discusses their basic structures and influencing factors. It also shows the common methods that are widely used for the isolation of phytochemicals, as well as other procedures that enable further progress in the separation and identification of these compounds. Observational studies indicate that oak polyphenols may provide enhancement effects on wine aging systems with a significant improvement in the wine's color, aroma and taste. Furthermore, oak polyphenols possess various activities, such as anticancer, antioxidant, antidiabetic, antihypertensive, and antimicrobial properties. Although many studies have focused on the oak polyphenols, researchers have failed to provide comprehensive knowledge of their functions during the aging process, such as the mechanism of flavor enhancement and color stability. Moreover, limited information exists on the bioactivity of phytochemicals. For example, what dosage of phenolic compounds can be considered effective for either short-term or long-term effects? Do interactions exist with other nutrients in food? To obtain the answers to the aforementioned questions, further study should be conducted.

\section{Acknowledgments}

The authors gratefully acknowledge the financial support received from National Natural Science Foundation of China (Grant No. 31271926) and China Agriculture Research System for Grape Industry (CARS-30).

\section{Author Contributions}

Bo Zhang and Jian Cai contributed to data interpretation and integration and drafting of the manuscript; Chang-Qing Duan contributed to article design, references management and critical revision of the manuscript for important intellectual content; Malcolm J. Reeves contributed to critical revision of the manuscript for important intellectual content; Fei He contributed to conception generation and design of the review.

\section{Conflicts of Interest}

The authors declare no conflict of interest.

\section{References}

1. Lnnhenheimer, F. Amphoras and Shipwrecks: Wine from the Tyrrhenian Coast at the End of the Republic and Its Distribution in Gaul; Wiley-Blackwell: Oxford, UK, 2013; p. 97.

2. Sun, Z. Accelerated Seasoning of Manuka and Oak Wood Chips Destined for Wine and Spirit Flavour. Master's Thesis, AUT University, Auckland, New Zealand, December 2013. 
3. Johnson, H.; Robinson, J. The World Atlas of Wine; Mitchell Beazley: London, UK, 2001; Volume 1.

4. Charters, S. Wine and Society; Butterworth-Heinemann: Oxford, UK, 2006.

5. Fernández de Simón, B.; Cadahía, E.; Conde, E.; García-Vallejo, M.C. Low molecular weight phenolic compounds in spanish oak woods. J. Agric. Food Chem. 1996, 44, 1507-1511.

6. Nonier, M.F.; Vivas, N.; Vivas de Gaulejac, N.; Absalon, C.; Soulié, P.; Fouquet, E. Pyrolysis-gas chromatography/mass spectrometry of Quercus sp. Wood: Application to structural elucidation of macromolecules and aromatic profiles of different species. J. Anal. Appl. Pyrolysis 2006, 75, 181-193.

7. Glabasnia, A.; Hofmann, T. Sensory-directed identification of taste-active ellagitannins in American (Quercus alba L.) and European oak wood (Quercus robur L.) and quantitative analysis in bourbon whiskey and oak-matured red wines. J. Agric. Food Chem. 2006, 54, 3380-3390.

8. Cadahía, E.; Varea, S.; Muñoz, L.; Fernández de Simón, B.; García-Vallejo, M.C. Evolution of ellagitannins in Spanish, French, and American oak woods during natural seasoning and toasting. J. Agric. Food Chem. 2001, 49, 3677-3684.

9. Hernández, T.; Estrella, I.; Dueñas, M.; de Simón, B.F.; Cadahía, E. Influence of wood origin in the polyphenolic composition of a Spanish red wine aging in bottle, after storage in barrels of Spanish, French and American oak wood. Eur. Food Res. Technol. 2007, 224, 695-705.

10. De Simón, B.F.; Hernández, T.; Cadahía, E.; Dueñas, M.; Estrella, I. Phenolic compounds in a Spanish red wine aged in barrels made of Spanish, French and American oak wood. Eur. Food Res. Technol. 2003, 216, 150-156.

11. Prida, A.; Puech, J.L. Influence of geographical origin and botanical species on the content of extractives in American, French, and East European oak woods. J. Agric. Food Chem. 2006, 54, 8115-8126.

12. Ibern-Gómez, M.; Andrés-Lacueva, C.; Lamuela-Raventós, R.M.; Lao-Luque, C.; Buxaderas, S.; de la Torre-Boronat, M.C. Differences in phenolic profile between oak wood and stainless steel fermentation in white wines. Am. J. Enol. Viticult. 2001, 52, 159-164.

13. Canas, S.; Quaresma, H.; Belchior, A.P.; Spranger, M.I.; Bruno-de-Sousa, R. Evaluation of wine brandies authenticity by the relationships between benzoic and cinnamic aldehydes and between furanic aldehydes. Ciênc. Téc. Vitivinic. 2004, 19, 13-27.

14. Fujieda, M.; Tanaka, T.; Suwa, Y.; Koshimizu, S.; Kouno, I. Isolation and structure of whiskey polyphenols produced by oxidation of oak wood ellagitannins. J. Agric. Food Chem. 2008, 56, 7305-7310.

15. Heras, M.O.; Rivero-Pérez, M.D.; Pérez-Magariño, S.; González-Huerta, C.; González-Sanjosé, M.L. Changes in the volatile composition of red wines during aging in oak barrels due to microoxygenation treatment applied before malolactic fermentation. Eur. Food Res. Technol. 2008, 226, 1485-1493.

16. Pérez-Magariño, S.; Sánchez-Iglesias, M.; Ortega-Heras, M.; González-Huerta, C.; González-Sanjosé, M.L. Colour stabilization of red wines by microoxygenation treatment before malolactic fermentation. Food Chem. 2007, 101, 881-893.

17. Sousa, A.; Mateus, N.; Silva, A.M.S.; Vivas, N.; Nonier, M.-F.; Pianet, I.; de Freitas, V. Isolation and structural characterization of anthocyanin-furfuryl pigments. J. Agric. Food Chem. 2010, 58, 5664-5669. 
18. Saucier, C.; Jourdes, M.; Glories, Y.; Quideau, S. Extraction, detection, and quantification of flavano-ellagitannins and ethylvescalagin in a bordeaux red wine aged in oak barrels. J. Agric. Food Chem. 2006, 54, 7349-7354.

19. Pissarra, J.; Lourenco, S.; González-Paramás, A.M.; Mateus, N.; Buelga, C.S.; Silva, A.M.S.; de Freitas, V. Isolation and structural characterization of new anthocyanin-alkyl-catechin pigments. Food Chem. 2005, 90, 81-87.

20. Madrera, R.R.; Valles, B.S.; García, Y.D.; del Valle Argüelles, P.; Lobo, A.P. Alternative woods for aging distillates-an insight into their phenolic profiles and antioxidant activities. Food Sci. Biotechnol. 2010, 19, 1129-1134.

21. Setzer, W.N. Lignin-derived oak phenolics: A theoretical examination of additional potential health benefits of red wine. J. Mol. Model. 2011, 17, 1841-1845.

22. Alañón, M.E.; Castro-Vázquez, L.; Díaz-Maroto, M.C.; Hermosín-Gutiérrez, I.; Gordon, M.H.; Pérez-Coello, M.S. Antioxidant capacity and phenolic composition of different woods used in cooperage. Food Chem. 2011, 129, 1584-1590.

23. Bravo, L. Polyphenols: Chemistry, dietary sources, metabolism, and nutritional significance. Nutr. Rev. 1998, 56, 317-333.

24. Deshpande, S.S.; Sathe, S.K.; Salunkhe, D.K. Chemistry and safety of plant polyphenols. In Nutritional and Toxicological Aspects of Food Safety; Plenum Press: New York, NY, USA, 1984; pp. 457-495.

25. Ananga, A.; Georgiev, V.; Tsolova, V. Manipulation and engineering of metabolic and biosynthetic pathway of plant polyphenols. Curr. Pharm. Des. 2013, 19, 6186-6206.

26. Hichri, I.; Barrieu, F.; Bogs, J.; Kappel, C.; Delrot, S.; Lauvergeat, V. Recent advances in the transcriptional regulation of the flavonoid biosynthetic pathway. J. Exp. Bot. 2011, 62, 2465-2483.

27. De Vries, G.E. Flavonoid biosynthetic pathway. Trends. Plant Sci. 2000, 5, 7.

28. Wollgast, J.; Anklam, E. Review on polyphenols in Theobroma cacao changes in composition during the manufacture of chocolate and methodology for identification and quantification. Food Res. Int. 2000, 33, 423-447

29. Ross, J.A.; Kasum, C.M. Dietary flavonoids: Bioavailability, metabolic effects, and safety. Annu. Rev. Nutr. 2002, 22, 19-34.

30. Cuyckens, F.; Claeys, M. Mass spectrometry in the structural analysis of flavonoids. J. Mass Spectrom. 2004, 39, 1-15.

31. Herrmann, K. Flavonols and flavones in food plants: A review. Int. J. Food Sci. Technol. 1976, 11, 433-448.

32. Manach, C.; Scalbert, A.; Morand, C.; Rémésy, C.; Jiménez, L. Polyphenols: Food sources and bioavailability. Am. J. Clin. Nutr. 2004, 79, 727-747.

33. Rentzsch, M.; Wilkens, A.; Winterhalter, P. Non-flavonoid phenolic compounds. In Wine Chemistry and Biochemistry; Springer: New York, NY, USA, 2009; pp. 509-527.

34. Gonçalves, J.; Silva, C.L.; Castilho, P.C.; Câmara, J.S. An attractive, sensitive and high-throughput strategy based on microextraction by packed sorbent followed by UHPLC-PDA analysis for quantification of hydroxybenzoic and hydroxycinnamic acids in wines. Microchem. J. 2013, 106, $129-138$. 
35. Cartea, M.E.; Francisco, M.; Soengas, P.; Velasco, P. Phenolic compounds in brassica vegetables. Molecules 2010, 16, 251-280.

36. Crozier, A.; Jaganath, I.B.; Clifford, M.N. Phenols, polyphenols and tannins: An overview. In Plant Secondary Metabolites: Occurrence, Structure and Role in the Human Diet; Wiley-Blackwell: Oxford, UK, 2006; pp. 1-24.

37. Kanerva, S. Plant Secondary Compounds and Soil Microbial Processes in Carbon and Nitrogen Cycling in Relation to Tree Species. Ph.D. Thesis, University of Helsinki, Helsinki, Finland, December 2007.

38. Liu, P. Composition of Hawthorn (Crataegus spp.) Fruits and Leaves and Emblic Leafflower (Phyllanthus emblica) Fruits. Ph.D. Thesis, University of Turku, Turku, Finland, May 2012.

39. Arapitsas, P. Hydrolyzable tannin analysis in food. Food Chem. 2012, 135, 1708-1717.

40. Alañón, M.E.; Castro-Vázquez, L.; Díaz-Maroto, M.C.; Gordon, M.H.; Pérez-Coello, M.S. A study of the antioxidant capacity of oak wood used in wine ageing and the correlation with polyphenol composition. Food Chem. 2011, 128, 997-1002.

41. Carrillo, J.D.; Garrido-López, Á.; Tena, M.T. Determination of volatile oak compounds in wine by headspace solid-phase microextraction and gas chromatography-mass spectrometry. J. Chromatogr. A 2006, 1102, 25-36.

42. Pollnitz, A.P.; Pardon, K.H.; Sykes, M.; Sefton, M.A. The effects of sample preparation and gas chromatograph injection techniques on the accuracy of measuring guaiacol, 4-methylguaiacol and other volatile oak compounds in oak extracts by stable isotope dilution analyses. J. Agric. Food Chem. 2004, 52, 3244-3252.

43. Marín, J.; Zalacain, A.; de Miguel, C.; Alonso, G.L.; Salinas, M.R. Stir bar sorptive extraction for the determination of volatile compounds in oak-aged wines. J. Chromatogr. A 2005, 1098, 1-6.

44. Guth, H. Quantitation and sensory studies of character impact odorants of different white wine varieties. J. Agric. Food Chem. 1997, 45, 3027-3032.

45. Jarauta, I.; Cacho, J.; Ferreira, V. Concurrent phenomena contributing to the formation of the aroma of wine during aging in oak wood: An analytical study. J. Agric. Food Chem. 2005, 53, 4166-4177.

46. Schwarz, M.; Wabnitz, T.C.; Winterhalter, P. Pathway leading to the formation of anthocyanin-vinylphenol adducts and related pigments in red wines. J. Agric. Food Chem. 2003, 51,3682-3687.

47. Natali, N.; Chinnici, F.; Riponi, C. Characterization of volatiles in extracts from oak chips obtained by accelerated solvent extraction (ASE). J. Agric. Food Chem. 2006, 54, 8190-8198.

48. Fernández de Simón, B.G.; Esteruelas, E.; Muñoz, A.N.M.; Cadahía, E.; Sanz, M. Volatile compounds in acacia, chestnut, cherry, ash, and oak woods, with a view to their use in cooperage. J. Agric. Food Chem. 2009, 57, 3217-3227.

49. De Simón, B.F.; Muiño, I.; Cadahía, E. Characterization of volatile constituents in commercial oak wood chips. J. Agric. Food Chem. 2010, 58, 9587-9596.

50. Del Alamo Sanza, M.; Nevares Domınguez, I.; Cárcel Cárcel, L.M.; Navas Gracia, L. Analysis for low molecular weight phenolic compounds in a red wine aged in oak chips. Anal. Chim. Acta 2004, 513, 229-237.

51. Da Silva, A.A.; do Nascimento, E.S.P.; Cardoso, D.R.; Franco, D.W. Coumarins and phenolic fingerprints of oak and Brazilian woods extracted by sugarcane spirit. J. Sep. Sci. 2009, 32, 3681-3691. 
52. Fernández de Simón, B.; Sanz, M.; Cadahía, E.; Poveda, P.; Broto, M. Chemical characterization of oak heartwood from Spanish forests of Quercus pyrenaica (wild.). Ellagitannins, low molecular weight phenolic, and volatile compounds. J. Agric. Food Chem. 2006, 54, 8314-8321.

53. Cadahía, E.; Muñoz, L.; Fernández de Simón, B.; García-Vallejo, M.C. Changes in low molecular weight phenolic compounds in Spanish, French, and American oak woods during natural seasoning and toasting. J. Agric. Food Chem. 2001, 49, 1790-1798.

54. Dos Anjos, J.P.; das Cardoso, M.G.; Saczk, A.A.; Dórea, H.S.; Santiago, W.D.; Machado, A.M.R.; Zacaroni, L.M.; Nelson, D.L. Evolution of the concentration of phenolic compounds in cachaça during aging in an oak (Quercus sp.) barrel. J. Braz. Chem. Soc. 2011, 22, 1307-1314.

55. Regalado, E.L.; Tolle, S.; Pino, J.A.; Winterhalter, P.; Menendez, R.; Morales, A.R.; Rodríguez, J.L. Isolation and identification of phenolic compounds from rum aged in oak barrels by high-speed countercurrent chromatography/high-performance liquid chromatography-diode array detection-electrospray ionization mass spectrometry and screening for antioxidant activity. J. Chromatogr. A 2011, 1218, 7358-7364.

56. Cabrita, M.J.; Barrocas Dias, C.; Costa Freitas, A.M. Phenolic acids, phenolic aldehydes and furanic derivatives in oak chips: American vs. French oaks. S. Afr. J. Enol. Vitic. 2011, 32, 204-210.

57. Nonier Bourden, M.F.; Vivas, N.; Absalon, C.; Vitry, C.; Fouquet, E.; Vivas de Gaulejac, N. Structural diversity of nucleophilic adducts from flavanols and oak wood aldehydes. Food Chem. 2008, 107, 1494-1505.

58. Zhang, B.; Liu, R.; He, F.; Zhou, P.-P.; Duan, C.-Q. Copigmentation of malvidin-3-O-glucoside with five hydroxybenzoic acids in red wine model solutions: Experimental and theoretical investigations. Food Chem. 2015, 170, 226-233.

59. Eiro, M.J.; Heinonen, M. Anthocyanin color behavior and stability during storage: Effect of intermolecular copigmentation. J. Agric. Food Chem. 2002, 50, 7461-7466.

60. Boulton, R. The copigmentation of anthocyanins and its role in the color of red wine: A critical review. Am. J. Enol. Vitic. 2001, 52, 67-87.

61. Sun, J.; Cao, X.; Liao, X.; Hu, X. Comparative analyses of copigmentation of cyanidin 3-glucoside and cyanidin 3-sophoroside from red raspberry fruits. Food Chem. 2010, 120, 1131-1137.

62. Viriot, C.; Scalbert, A.; Lapierre, C.; Moutounet, M. Ellagitannins and lignins in aging of spirits in oak barrels. J. Agric. Food Chem. 1993, 41, 1872-1879.

63. Landete, J.M. Ellagitannins, ellagic acid and their derived metabolites: A review about source, metabolism, functions and health. Food Res. Int. 2011, 44, 1150-1160.

64. Ree, T. Tannins: Classification and definition. Nat. Prod. Rep. 2001, 18, 641-649.

65. Niemetz, R.; Gross, G.G. Enzymology of gallotannin and ellagitannin biosynthesis. Phytochemistry 2005, 66, 2001-2011.

66. Michel, J.; Jourdes, M.; Silva, M.A.; Giordanengo, T.; Mourey, N.; Teissedre, P.-L. Impact of concentration of ellagitannins in oak wood on their levels and organoleptic influence in red wine. J. Agric. Food Chem. 2011, 59, 5677-5683.

67. Masson, G.; Moutounet, M.; Puech, J.L. Ellagitannin content of oak wood as a function of species and of sampling position in the tree. Am. J. Enol. Vitic. 1995, 46, 262-268. 
68. Doussot, F.; de Jéso, B.; Quideau, S.; Pardon, P. Extractives content in cooperage oak wood during natural seasoning and toasting; Influence of tree species, geographic location, and single-tree effects. J. Agric. Food Chem. 2002, 50, 5955-5961.

69. Mila, I.; Scalbert, A.; Expert, D. Iron withholding by plant polyphenols and resistance to pathogens and rots. Phytochemistry 1996, 42, 1551-1555.

70. Mosedale, J.R.; Puech, J.L.; Feuillat, F. The influence on wine flavor of the oak species and natural variation of heartwood components. Am. J. Enol. Vitic. 1999, 50, 503-512.

71. Quideau, S.; Jourdes, M.; Lefeuvre, D.; Montaudon, D.; Saucier, C.; Glories, Y.; Pardon, P.; Pourquier, P. The chemistry of wine polyphenolic $C$-glycosidic ellagitannins targeting human topoisomerase II. Chem.-A Eur. J. 2005, 11, 6503-6513.

72. Chassaing, S.; Lefeuvre, D.; Jacquet, R.; Jourdes, M.; Ducasse, L.; Galland, S.; Grelard, A.; Saucier, C.; Teissedre, P.L.; Dangles, O. Physicochemical studies of new anthocyano-ellagitannin hybrid pigments: About the origin of the influence of oak $C$-glycosidic ellagitannins on wine color. Eur. J. Org. Chem. 2010, 2010, 55-63.

73. Alañón, M.E.; Schumacher, R.; Castro-Vázquez, L.; Díaz-Maroto, M.C.; Hermosín-Gutiérrez, I.; Pérez-Coello, M.S. Enological potential of chestnut wood for aging tempranillo wines part II: Phenolic compounds and chromatic characteristics. Food Res. Int. 2013, 51, 536-543.

74. Sanz, M.; Fernandez de Simon, B.; Esteruelas, E.; Munoz, A.M.; Cadahia, E.; Hernandez, M.T.; Estrella, I.; Martinez, J. Polyphenols in red wine aged in acacia (Robinia pseudoacacia) and oak (Quercus petraea) wood barrels. Anal. Chim. Acta 2012, 732, 83-90.

75. Springmann, S.; Rogers, R.; Spiecker, H. Impact of artificial pruning on growth and secondary shoot development of wild cherry (Prunus avium L.). For. Ecol. Manag. 2011, 261, 764-769.

76. Fernandez de Simon, B.; Sanz, M.; Cadahia, E.; Martinez, J.; Esteruelas, E.; Munoz, A.M. Polyphenolic compounds as chemical markers of wine ageing in contact with cherry, chestnut, false acacia, ash and oak wood. Food Chem. 2014, 143, 66-76.

77. Comandini, P.; Lerma-Garcia, M.J.; Simo-Alfonso, E.F.; Toschi, T.G. Tannin analysis of chestnut bark samples (Castanea sativa Mill.) by HPLC-DAD-MS. Food Chem. 2014, 157, 290-295.

78. Sanz, M.; Fernandez de Simon, B.; Cadahia, E.; Esteruelas, E.; Munoz, A.M.; Hernandez, M.T.; Estrella, I. Polyphenolic profile as a useful tool to identify the wood used in wine aging. Anal. Chim. Acta 2012, 732, 33-45.

79. Fernandez de Simon, B.; Martinez, J.; Sanz, M.; Cadahia, E.; Esteruelas, E.; Munoz, A.M. Volatile compounds and sensorial characterisation of red wine aged in cherry, chestnut, false acacia, ash and oak wood barrels. Food Chem. 2014, 147, 346-356.

80. Towey, J.P.; Waterhouse, A.L. Barrel-to-barrel variation of volatile oak extractives in barrel-fermented chardonnay. Am. J. Enol. Vitic. 1996, 47, 17-20.

81. Puech, J.L.; Feuillat, F.; Mosedale, J.R. The tannins of oak heartwood: Structure, properties, and their influence on wine flavor. Am. J. Enol. Vitic. 1999, 50, 469-478.

82. Fan, W.; Xu, Y.; Yu, A. Influence of oak chips geographical origin, toast level, dosage and aging time on volatile compounds of apple cider. J. Inst. Brew. 2006, 112, 255-263.

83. Guchu, E.; Díaz-Maroto, M.C.; Díaz-Maroto, I.J.; Vila-Lameiro, P.; Pérez-Coello, M.S. Influence of the species and geographical location on volatile composition of Spanish oak wood (Quercus petraea Liebl. and Quercus robur L.). J. Agric. Food Chem. 2006, 54, 3062-3066. 
84. Fernández de Simón, B.; Cadahía, E.; Conde, E.; García-Vallejo, M.C. Evolution of phenolic compounds of Spanish oak wood during natural seasoning. First results. J. Agric. Food Chem. 1999, 47, 1687-1694.

85. Escalona, H.; Birkmyre, L.; Piggott, J.R.; Paterson, A. Effect of maturation in small oak casks on the volatility of red wine aroma compounds. Anal. Chim. Acta 2002, 458, 45-54.

86. Miller, D.P.; Howell, G.S.; Michaelis, C.S.; Dickmann, D.I. The content of phenolic acid and aldehyde flavor components of white oak as affected by site and species. Am. J. Enol. Vitic. 1992, 43, 333-338.

87. Glabasnia, A.; Hofmann, T. Identification and sensory evaluation of dehydro-and deoxy-ellagitannins formed upon toasting of oak wood (Quercus alba L.). J. Agric. Food Chem. 2007, 55, 4109-4118.

88. Sefton, M.A.; Francis, I.L.; Pocock, K.F.; Williams, P.J. The influence of natural seasoning on the concentrations of eugenol, vanillin, and cis-and trans- $\beta$-methyl- $\gamma$-octalactone extracted from French and American oakwood. Sci. Des. Aliment. 1993, 13, 629-643.

89. Pérez-Coello, M.S.; Díaz-Maroto, M.C. Volatile compounds and wine aging. In Wine Chemistry and Biochemistry; Springer: New York, NY, USA, 2009; pp. 295-311.

90. Pérez-Coello, M.S.; Sanz, J.; Cabezudo, M.D. Determination of volatile compounds in hydroalcoholic extracts of french and american oak wood. Am. J. Enol. Vitic. 1999, 50, 162-165.

91. Prida, A.; Boulet, J.-C.; Ducousso, A.; Nepveu, G.; Puech, J.-L. Effect of species and ecological conditions on ellagitannin content in oak wood from an even-aged and mixed stand of Quercus robur L. And Quercus petraea Liebl. Ann. For. Sci. 2006, 63, 415-424.

92. Gallego, L.; del Alamo, M.; Nevares, I.; Fernández, J.A.; de Simón, B.F.; Cadahía, E. Phenolic compounds and sensorial characterization of wines aged with alternative to barrel products made of Spanish oak wood (Quercus pyrenaica Willd.). Food Sci. Technol. Int. 2012, 18, 151-165.

93. Chatonnet, P.; Boidron, J.N.; Dubourdieu, D.; Pons, M. Evolution of oakwood polyphenolic compounds during seasoning. First results. J. Int. Sci. Vigne Vin 1994, 28, 337-357.

94. Bate-Smith, E.C. The commoner phenolic constituents of plants and their systematic distribution. Proc. R. Dublin Sci. Soc. 1956, 27, 165-176.

95. Matricardi, L.; Waterhouse, A.L. Influence of toasting technique on color and ellagitannins of oak wood in barrel making. Am. J. Enol. Vitic. 1999, 50, 519-526.

96. Frangipane, M.T.; Santis, D.D.; Ceccarelli, A. Influence of oak woods of different geographical origins on quality of wines aged in barriques and using oak chips. Food Chem. 2007, 103, 46-54.

97. Chatonnet, P.; Cutzach, I.; Pons, M.; Dubourdieu, D. Monitoring toasting intensity of barrels by chromatographic analysis of volatile compounds from toasted oak wood. J. Agric. Food Chem. 1999, 47, 4310-4318.

98. Sarni, F.; Moutounet, M.; Puech, J.-L.; Rabier, P. Effect of heat treatment of oak wood extractable compounds. Holzforschung 1990, 44, 461-466.

99. Jordão, A.M.; Correia, A.C.; DelCampo, R.; SanJosé, M.L.G. Antioxidant capacity, scavenger activity, and ellagitannins content from commercial oak pieces used in winemaking. Eur. Food Res. Technol. 2012, 235, 817-825.

100. Tao, Y.; García, J.F.; Sun, D.-W. Advances in wine ageing technologies for enhancing wine quality and accelerating wine ageing process. Crit. Rev. Food Sci. Nutr. 2014, 54, 817-835. 
101. Pérez-Prieto, L.J.; López-Roca, J.M.; Martínez-Cutillas, A.; Pardo-Mínguez, F.; Gómez-Plaza, E. Extraction and formation dynamic of oak-related volatile compounds from different volume barrels to wine and their behavior during bottle storage. J. Agric. Food Chem. 2003, 51, 5444-5449.

102. Spillman, P.J.; Iland, P.G.; Sefton, M.A. Accumulation of volatile oak compounds in a model wine stored in American and Limousin oak barrels. Aust. J. Grape Wine Res. 1998, 4, 67-73.

103. Rodríguez-Rodríguez, P.; Gómez-Plaza, E. Effect of volume and toast level of french oak barrels (Quercus petraea L.) on cabernet sauvignon wine characteristics. Am. J. Enol. Vitic. 2011, 62, 359-365.

104. Charrier, B.; Janin, G.; Haluk, J.P.; Mosedale, J.R. Colour and chemical characteristics of moon rings in oakwood. Holzforschung 1995, 49, 287-292.

105. Viriot, C.; Scalbert, A.; Hervé du Penhoat, C.L.M.; Moutounet, M. Ellagitannins in woods of sessile oak and sweet chestnut dimerization and hydrolysis during wood ageing. Phytochemistry 1994, 36, 1253-1260.

106. Mosedale, J.R.; Savill, P.S. Variation of heartwood phenolics and oak lactones between the species and phenological types of Quercus petraea and Q. robur. Forestry 1996, 69, 47-55.

107. Mosedale, J.R.; Charrier, B.; Janin, G. Genetic control of wood colour, density and heartwood ellagitannin concentration in european oak (Quercus petraea and Q. Robur). Forestry 1996, 69, 111-124.

108. Sanz, M.; Cadahía, E.; Esteruelas, E.; Muñoz, A.N.M.; Fernández De Simón, B.G.; Hernández, T.; Estrella, I. Phenolic compounds in cherry (Prunus avium) heartwood with a view to their use in cooperage. J. Agric. Food Chem. 2010, 58, 4907-4914.

109. Shen, C.; Jun, H.; Choi, S.; Kim, Y.; Jung, E.; Oh, G.; Joo, S.; Kim, S.; Kim, I. Evaluation of antioxidant activities and active compounds separated from water soluble extracts of Korean black pine barks. Bull. Korean Chem. Soc. 2010, 31, 3567-3572.

110. Sanz, M.; Fernández de Simón, B.G.; Esteruelas, E.; Muñoz, A.N.M.; Cadahía, E.; Hernández, T.; Estrella, I.; Pinto, E. Effect of toasting intensity at cooperage on phenolic compounds in acacia (Robinia pseudoacacia) heartwood. J. Agric. Food Chem. 2011, 59, 3135-3145.

111. Jeffery, D.W.; Mercurio, M.D.; Herderich, M.J.; Hayasaka, Y.; Smith, P.A. Rapid isolation of red wine polymeric polyphenols by solid-phase extraction. J. Agric. Food Chem. 2008, 56, 2571-2580.

112. Cerezo, A.B.; Tesfaye, W.; Torija, M.J.; Mateo, E.; García-Parrilla, M.C.; Troncoso, A.M. The phenolic composition of red wine vinegar produced in barrels made from different woods. Food Chem. 2008, 109, 606-615.

113. Marrufo-Curtido, A.; Cejudo-Bastante, M.J.; Durán-Guerrero, E.; Castro-Mejías, R.; Natera-Marín, R.; Chinnici, F.; García-Barroso, C. Characterization and differentiation of high quality vinegars by stir bar sorptive extraction coupled to gas chromatography-mass spectrometry (SBSE-GC-MS). LWT-Food Sci. Technol. 2012, 47, 332-341.

114. Borges, G.; Crozier, A. HPLC-PDA-MS fingerprinting to assess the authenticity of pomegranate beverages. Food Chem. 2012, 135, 1863-1867.

115. Cao, X.; Wang, C.; Pei, H.; Sun, B. Separation and identification of polyphenols in apple pomace by high-speed counter-current chromatography and high-performance liquid chromatography coupled with mass spectrometry. J. Chromatogr. A 2009, 1216, 4268-4274. 
116. Bai, X.L.; Yue, T.L.; Yuan, Y.H.; Zhang, H.W. Optimization of microwave-passisted extraction of polyphenols from apple pomace using response surface methodology and HPLC analysis. J. Sep. Sci. 2010, 33, 3751-3758.

117. Rodríguez Galdón, B.; Rodríguez Rodríguez, E.M.; Díaz Romero, C. Flavonoids in onion cultivars (Allium cepa L.). J. Food Sci. 2008, 73, C599-C605.

118. Rodrigues, A.S.; Pérez-Gregorio, M.R.; García-Falcón, M.S.; Simal-Gándara, J. Effect of curing and cooking on flavonols and anthocyanins in traditional varieties of onion bulbs. Food Res. Int. 2009, 42, 1331-1336.

119. Rodrigues, A.S.; Pérez-Gregorio, M.R.; García-Falcón, M.S.; Simal-Gándara, J.; Almeida, D.P.F. Effect of post-harvest practices on flavonoid content of red and white onion cultivars. Food Control 2010, 21, 878-884.

120. Gelmez, N.; Kıncal, N.S.; Yener, M.E. Optimization of supercritical carbon dioxide extraction of antioxidants from roasted wheat germ based on yield, total phenolic and tocopherol contents, and antioxidant activities of the extracts. J. Supercrit. Fluids 2009, 48, 217-224.

121. Tomaino, A.; Martorana, M.; Arcoraci, T.; Monteleone, D.; Giovinazzo, C.; Saija, A. Antioxidant activity and phenolic profile of pistachio (Pistacia vera L., variety Bronte) seeds and skins. Biochimie 2010, 92, 1115-1122.

122. Singh, A.; Sabally, K.; Kubow, S.; Donnelly, D.J.; Gariepy, Y.; Orsat, V.; Raghavan, G.S.V. Microwave-assisted extraction of phenolic antioxidants from potato peels. Molecules 2011, 16, 2218-2232.

123. Fromm, M.; Bayha, S.; Carle, R.; Kammerer, D.R. Characterization and quantitation of low and high molecular weight phenolic compounds in apple seeds. J. Agric. Food Chem. 2012, 60, 1232-1242.

124. Iswaldi, I.; Arráez-Román, D.; Rodríguez-Medina, I.; Beltrán-Debón, R.; Joven, J.; Segura-Carretero, A.; Fernández-Gutiérrez, A. Identification of phenolic compounds in aqueous and ethanolic rooibos extracts (Aspalathus linearis) by HPLC-ESI-MS (TOF/IT). Anal. Bioanal. Chem. 2011, 400, 3643-3654.

125. Beelders, T.; Sigge, G.O.; Joubert, E.; de Beer, D.; de Villiers, A. Kinetic optimisation of the reversed phase liquid chromatographic separation of rooibos tea (Aspalathus linearis) phenolics on conventional high performance liquid chromatographic instrumentation. J. Chromatogr. A 2012, 1219, 128-139.

126. Grujic, N.; Lepojevic, Z.; Srdjenovic, B.; Vladic, J.; Sudji, J. Effects of different extraction methods and conditions on the phenolic composition of mate tea extracts. Molecules 2012, 17, 2518-2528.

127. Perestrelo, R.; Caldeira, M.; Barros, A.S.; Rocha, S.M.; Câmara, J.S. Solid phase microextraction as a reliable alternative to conventional extraction techniques to evaluate the pattern of hydrolytically released components in of Vitis vinifera L. grapes. Talanta 2012, 95, 1-11.

128. Palafox-Carlos, H.; Yahia, E.M.; González-Aguilar, G.A. Identification and quantification of major phenolic compounds from mango (Mangifera indica, cv. Ataulfo) fruit by HPLC-DAD-MS/ MS-ESI and their individual contribution to the antioxidant activity during ripening. Food Chem.

2012, 135, 105-111. 
129. Jerman Klen, T.; Mozetič Vodopivec, B. Optimisation of olive oil phenol extraction conditions using a high-power probe ultrasonication. Food Chem. 2012, 134, 2481-2488.

130. Naczk, M.; Shahidi, F. Extraction and analysis of phenolics in food. J. Chromatogr. A 2004, 1054, 95-111.

131. Naczk, M.; Shahidi, F. Phenolics in cereals, fruits and vegetables: Occurrence, extraction and analysis. J. Pharm. Biomed. Anal. 2006, 41, 1523-1542.

132. Antolovich, M.; Prenzler, P.; Robards, K.; Ryan, D. Sample preparation in the determination of phenolic compounds in fruits. Analyst 2000, 125, 989-1009.

133. Pinelo, M.; Fabbro, P.D.; Manzocco, L.; Nuñez, M.J.; Nicoli, M.C. Optimization of continuous phenol extraction from Vitis vinifera byproducts. Food Chem. 2005, 92, 109-117.

134. Nardini, M.; Cirillo, E.; Natella, F.; Mencarelli, D.; Comisso, A.; Scaccini, C. Detection of bound phenolic acids: Prevention by ascorbic acid and ethylenediaminetetraacetic acid of degradation of phenolic acids during alkaline hydrolysis. Food Chem. 2002, 79, 119-124.

135. Aaby, K.; Ekeberg, D.; Skrede, G. Characterization of phenolic compounds in strawberry (Fragaria $\times$ ananassa) fruits by different HPLC detectors and contribution of individual compounds to total antioxidant capacity. J. Agric. Food. Chem. 2007, 55, 4395-4406.

136. Hayouni, E.A.; Abedrabba, M.; Bouix, M.; Hamdi, M. The effects of solvents and extraction method on the phenolic contents and biological activities in vitro of Tunisian Quercus coccifera L. and Juniperus phoenicea L. fruit extracts. Food Chem. 2007, 105, 1126-1134.

137. Paniwnyk, L.; Beaufoy, E.; Lorimer, J.P.; Mason, T.J. The extraction of rutin from flower buds of Sophora japonica. Ultrason. Sonochem. 2001, 8, 299-301.

138. Paniwnyk, L.; Cai, H.; Albu, S.; Mason, T.J.; Cole, R. The enhancement and scale up of the extraction of anti-oxidants from Rosmarinus officinalis using ultrasound. Ultrason. Sonochem. 2009, 16, 287-292.

139. Ouyang, G.; Pawliszyn, J. SPME in environmental analysis. Anal. Bioanal. Chem. 2006, 386, 1059-1073.

140. Díaz-Maroto, M.C.; Sánchez-Palomo, E.; Pérez-Coello, M.S. Fast screening method for volatile compounds of oak wood used for aging wines by headspace SPME-GC-MS (SIM). J. Agric. Food Chem. 2004, 52, 6857-6861.

141. Kadim, D.; Mannheim, C.H. Kinetics of phenolic extraction during aging of model wine solution and white wine in oak barrels. Am. J. Enol. Vitic. 1999, 50, 33-39.

142. Robbins, R.J. Phenolic acids in foods: An overview of analytical methodology. J. Agric. Food Chem. 2003, 51, 2866-2887.

143. Barton, G.M.; Evans, R.S.; Gardner, J.A.F. Paper chromatography of phenolic substances. Nature 1952, 170, 249-250.

144. Quinn, M.K.; Singleton, V.L. Isolation and identification of ellagitannins from white oak wood and an estimation of their roles in wine. Am. J. Enol. Vitic. 1985, 36, 148-155.

145. Bele, A.A.; Khale, A. An overview on thin layer chromatography. Int. J. Pharm. Pharm. Sci. 2011, 2, 256-267.

146. Lepri, L.; Desideri, P.G.; Heimler, D. Reversed-phase and soap thin-layer chromatography of phenols. J. Chromatogr. A 1980, 195, 339-348. 
147. Harborne, J.B.; Williams, C.A. Advances in flavonoid research since 1992. Phytochemistry 2000, $55,481-504$.

148. De Beer, D.; Harbertson, J.F.; Kilmartin, P.A.; Roginsky, V.; Barsukova, T.; Adams, D.O.; Waterhouse, A.L. Phenolics: A comparison of diverse analytical methods. Am. J. Enol. Vitic. 2004, $55,389-400$.

149. Hellström, J.K.; Mattila, P.H. Hplc determination of extractable and unextractable proanthocyanidins in plant materials. J. Agric. Food Chem. 2008, 56, 7617-7624.

150. Herderich, M.J.; Smith, P.A. Analysis of grape and wine tannins: Methods, applications and challenges. Aust. J. Grape Wine Res. 2005, 11, 205-214.

151. Escarpa, A.; Gonzalez, M.C. Evaluation of high-performance liquid chromatography for determination of phenolic compounds in pear horticultural cultivars. Chromatographia 2000, 51, 37-43.

152. Mattila, P.; Kumpulainen, J. Determination of free and total phenolic acids in plant-derived foods by HPLC with diode-array detection. J. Agric. Food Chem. 2002, 50, 3660-3667.

153. Cui, T.; Li, J.-Z.; Kayahara, H.; Ma, L.; Wu, L.-X.; Nakamura, K. Quantification of the polyphenols and triterpene acids in Chinese hawthorn fruit by high-performance liquid chromatography. J. Agric. Food Chem. 2006, 54, 4574-4581.

154. Hathway, D.E. Oak-bark tannins. Biochem. J. 1958, 70, 34.

155. He, Z.; Xia, W.; Chen, J. Isolation and structure elucidation of phenolic compounds in Chinese olive (Canarium album L.) fruit. Eur. Food Res. Technol. 2008, 226, 1191-1196.

156. Dai, J.; Mumper, R.J. Plant phenolics: Extraction, analysis and their antioxidant and anticancer properties. Molecules 2010, 15, 7313-7352.

157. Du, F.; Zhang, B.; Zhou, H.; Yan, B.; Chen, L. Structure elucidation of nanoparticle-bound organic molecules by ${ }^{1}$ H NMR. TrAC Trends Anal. Chem. 2009, 28, 88-95.

158. Sudjaroen, Y.; Hull, W.E.; Erben, G.; Würtele, G.; Changbumrung, S.; Ulrich, C.M.; Owen, R.W. Isolation and characterization of ellagitannins as the major polyphenolic components of Longan (Dimocarpus longan Lour) seeds. Phytochemistry 2012, 77, 226-237.

159. Vivas, N.; Laguerre, M.; Glories, Y.; Bourgeois, G.; Vitry, C. Structure simulation of two ellagitannins from Quercus robur 1. Phytochemistry 1995, 39, 1193-1199.

160. Mabry, T.J.; Markham, K.R.; Thomas, M.B. The NMR spectra of flavonoids. In The Systematic Identification of Flavonoids; Springer: New York, NY, USA, 1970; pp. 274-343.

161. Slimestad, R. Flavonoids in buds and young needles of Picea, Pinus and Abies. Biochem. Syst. Ecol. 2003, 31, 1247-1255.

162. Perez-Gregorio, M.R.; Regueiro, J.; Simal-Gandara, J.; Rodrigues, A.S.; Almeida, D.P. Increasing the added-value of onions as a source of antioxidant flavonoids: A critical review. Crit. Rev. Food Sci. Nutr. 2014, 54, 1050-1062.

163. Crozier, A.; Jaganath, I.B.; Clifford, M.N. Dietary phenolics: Chemistry, bioavailability and effects on health. Nat. Prod. Rep. 2009, 26, 1001-1043.

164. Buendía, B.a.; Gil, M.a.I.; Tudela, J.A.; Gady, A.L.; Medina, J.J.; Soria, C.; López, J.M.; Tomás-Barberán, F.A. HPLC-MS analysis of proanthocyanidin oligomers and other phenolics in 15 strawberry cultivars. J. Agric. Food Chem. 2009, 58, 3916-3926.

165. Basu, A.; Nguyen, A.; Betts, N.M.; Lyons, T.J. Strawberry as a functional food: An evidence-based review. Crit. Rev. Food Sci. Nutr. 2014, 54, 790-806. 
166. Sun, L.; Guo, Y.; Fu, C.; Li, J.; Li, Z. Simultaneous separation and purification of total polyphenols, chlorogenic acid and phlorizin from thinned young apples. Food Chem. 2013, 136, 1022-1029.

167. Kammerer, D.R.; Kammerer, J.; Valet, R.; Carle, R. Recovery of polyphenols from the by-products of plant food processing and application as valuable food ingredients. Food Res. Int. 2014, 65, $2-12$.

168. Gîrzu, M.; Fraisse, D.; Carnat, A.-P.; Carnat, A.; Lamaison, J.-L. High-performance liquid chromatographic method for the determination of juglone in fresh walnut leaves. J. Chromatogr. A 1998, 805, 315-318.

169. Marceneiro, S.; Coimbra, P.; Braga, M.E.M.; Dias, A.M.A.; de Sousa, H.C. Measurement and correlation of the solubility of juglone in supercritical carbon dioxide. Fluid Phase Equilibria 2011, $311,1-8$.

170. Ruiz-Montañez, G.; Ragazzo-Sánchez, J.A.; Calderón-Santoyo, M.; Velázquez-de la Cruz, G.; de León, J.A.R.; Navarro-Ocaña, A. Evaluation of extraction methods for preparative scale obtention of mangiferin and lupeol from mango peels (Mangifera indica L.). Food Chem. 2014, 159, 267-272.

171. Jyotshna; Srivastava, P.; Killadi, B.; Shanker, K. Uni-dimensional double development HPTLC-densitometry method for simultaneous analysis of mangiferin and lupeol content in mango (Mangifera indica) pulp and peel during storage. Food Chem. 2015, 176, 91-98.

172. Liu, C.; Wang, L.; Wang, J.; Wu, B.; Liu, W.; Fan, P.; Liang, Z.; Li, S. Resveratrols in Vitis berry skins and leaves: Their extraction and analysis by HPLC. Food Chem. 2013, 136, 643-649.

173. Lopez-Alfaro, I.; Gonzalez-Arenzana, L.; Lopez, N.; Santamaria, P.; Lopez, R.; Garde-Cerdan, T. Pulsed electric field treatment enhanced stilbene content in Graciano, Tempranillo and Grenache grape varieties. Food Chem. 2013, 141, 3759-3765.

174. Gu, H.-F.; Li, C.-M.; Xu, Y.-J.; Hu, W.-F.; Chen, M.-H.; Wan, Q.-H. Structural features and antioxidant activity of tannin from persimmon pulp. Food Res. Int. 2008, 41, 208-217.

175. Wu, P.-W.; Hwang, L.S. Determination of soluble persimmon tannin by high performance gel permeation chromatography. Food Res. Int. 2002, 35, 793-800.

176. Hajiaghaalipour, F.; Kanthimathi, M.S.; Sanusi, J.; Rajarajeswaran, J. White tea (Camellia sinensis) inhibits proliferation of the colon cancer cell line, HT-29, activates caspases and protects DNA of normal cells against oxidative damage. Food Chem. 2015, 169, 401-410.

177. Sahpazidou, D.; Geromichalos, G.D.; Stagos, D.; Apostolou, A.; Haroutounian, S.A.; Tsatsakis, A.M.; Tzanakakis, G.N.; Hayes, A.W.; Kouretas, D. Anticarcinogenic activity of polyphenolic extracts from grape stems against breast, colon, renal and thyroid cancer cells. Toxicol. Lett. 2014, 230, $218-224$.

178. Rodrigues, A.S.; Pérez-Gregorio, M.R.; García-Falcón, M.S.; Simal-Gándara, J.; Almeida, D.P.F. Effect of meteorological conditions on antioxidant flavonoids in Portuguese cultivars of white and red onions. Food Chem. 2011, 124, 303-308.

179. Ruiz-Canela, M.; Martínez-González, M.A. Olive oil in the primary prevention of cardiovascular disease. Maturitas 2011, 68, 245-250.

180. Kaur, J.; Kaur, G. An insight into the role of citrus bioactives in modulation of colon cancer. J. Funct. Foods 2015, 13, 239-261. 
181. Yamanaka, F.; Hatano, T.; Ito, H.; Taniguchi, S.; Takahashi, E.; Okamoto, K. Antibacterial effects of guava tannins and related polyphenols on Vibrio and Aeromonas species. Nat. Prod. Commun. 2008, 3, 711-720.

182. Tripoli, E.; Guardia, M.L.; Giammanco, S.; Majo, D.D.; Giammanco, M. Citrus flavonoids: Molecular structure, biological activity and nutritional properties: A review. Food Chem. 2007, 104, 466-479.

183. Wen, X.-B.; Miao, F.; Zhou, L.; Zhang, M.; He, Q.-L. In vitro antioxidant activity of Parnassia wightiana W. extracts. Chin. J. Nat. Med. 2012, 10, 190-195.

184. Pérez-Gregorio, M.R.; González-Barreiro, C.; Rial-Otero, R.; Simal-Gándara, J. Comparison of sanitizing technologies on the quality appearance and antioxidant levels in onion slices. Food Control 2011, 22, 2052-2058.

185. Pérez-Gregorio, M.R.; Regueiro, J.; González-Barreiro, C.; Rial-Otero, R.; Simal-Gándara, J. Changes in antioxidant flavonoids during freeze-drying of red onions and subsequent storage. Food Control 2011, 22, 1108-1113.

186. Figueiredo-González, M.; Cancho-Grande, B.; Simal-Gándara, J. Effects on colour and phenolic composition of sugar concentration processes in dried-on- or dried-off-vine grapes and their aged or not natural sweet wines. Trends Food Sci. Technol. 2013, 31, 36-54.

187. Quijada-Morin, N.; Regueiro, J.; Simal-Gandara, J.; Tomas, E.; Rivas-Gonzalo, J.C.; Escribano-Bailon, M.T. Relationship between the sensory-determined astringency and the flavanolic composition of red wines. J. Agric. Food Chem. 2012, 60, 12355-12361.

188. Li, W.; Hydamaka, A.; Lowry, L. Comparison of antioxidant capacity and phenolic compounds of berries, chokecherry and seabuckthorn. Open Life Sci. 2009, 4, 499-506.

189. Pieszka, M.; Tombarkiewicz, B.; Roman, A.; Migdal, W.; Niedziolka, J. Effect of bioactive substances found in rapeseed, raspberry and strawberry seed oils on blood lipid profile and selected parameters of oxidative status in rats. Environ. Toxicol. Pharmacol. 2013, 36, 1055-1062.

190. D’Angelo, S.; Cimmino, A.; Raimo, M.; Salvatore, A.; Zappia, V.; Galletti, P. Effect of reddening-ripening on the antioxidant activity of polyphenol extracts from cv. "Annurca" apple fruits. J. Agric. Food Chem. 2007, 55, 9977-9985.

191. Stracke, B.A.; Rüfer, C.E.; Weibel, F.P.; Bub, A.; Watzl, B. Three-year comparison of the polyphenol contents and antioxidant capacities in organically and conventionally produced apples (Malus domestica bork. Cultivar "golden delicious"). J. Agric. Food Chem. 2009, 57, 4598-4605.

192. Reque, P.M.; Steffens, R.S.; Jablonski, A.; Flôres, S.H.; de O. Rios, A.; de Jong, E.V. Cold storage of blueberry (Vaccinium spp.) fruits and juice: Anthocyanin stability and antioxidant activity. J. Food Compos. Anal. 2014, 33, 111-116.

193. Wang, S.Y.; Chen, H.; Camp, M.J.; Ehlenfeldt, M.K. Flavonoid constituents and their contribution to antioxidant activity in cultivars and hybrids of rabbiteye blueberry (Vaccinium ashei reade). Food Chem. 2012, 132, 855-864.

194. Kosinska-Cagnazzo, A.; Diering, S.; Prim, D.; Andlauer, W. Identification of bioaccessible and uptaken phenolic compounds from strawberry fruits in in vitro digestion/Caco-2 absorption model. Food Chem. 2015, 170, 288-294. 
195. McKay, D.L.; Chen, C.Y.; Zampariello, C.A.; Blumberg, J.B. Flavonoids and phenolic acids from cranberry juice are bioavailable and bioactive in healthy older adults. Food Chem. 2015, 168, 233-240.

196. Hyson, D.A. A comprehensive review of apples and apple components and their relationship to human health. Adv. Nutr. 2011, 2, 408-420.

197. Ali, F.; Ismail, A.; Esa, N.M.; Pei, C.P. Transcriptomics expression analysis to unveil the molecular mechanisms underlying the cocoa polyphenol treatment in diet-induced obesity rats. Genomics 2015, 105, 23-30.

198. Sanbongi, C.; Suzuki, N.; Sakane, T. Polyphenols in chocolate, which have antioxidant activity, modulate immune functions in humans in vitro. Cell. Immunol. 1997, 177, 129-136.

(C) 2015 by the authors; licensee MDPI, Basel, Switzerland. This article is an open access article distributed under the terms and conditions of the Creative Commons Attribution license (http://creativecommons.org/licenses/by/4.0/). 